\title{
Numerical modelling of climate change impacts on freshwater lenses on the North Sea Island of Borkum using hydrological and geophysical methods
}

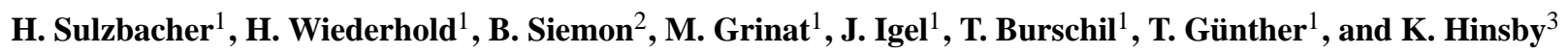 \\ ${ }^{1}$ Leibniz Institute for Applied Geophysics, Hannover, Germany \\ ${ }^{2}$ Federal Institute for Geosciences and Natural Resources, Hannover, Germany \\ ${ }^{3}$ Geological Survey of Denmark and Greenland, Copenhagen, Denmark
}

Correspondence to: H. Sulzbacher (hans.sulzbacher@liag-hannover.de)

Received: 21 February 2012 - Published in Hydrol. Earth Syst. Sci. Discuss.: 15 March 2012

Revised: 31 July 2012 - Accepted: 26 August 2012 - Published: 16 October 2012

\begin{abstract}
A numerical, density dependent groundwater model is set up for the North Sea Island of Borkum to estimate climate change impacts on coastal aquifers and especially the situation of barrier islands in the Wadden Sea. The database includes information from boreholes, a seismic survey, a helicopter-borne electromagnetic (HEM) survey, monitoring of the freshwater-saltwater boundary by vertical electrode chains in two boreholes, measurements of groundwater table, pumping and slug tests, as well as water samples. Based on a statistical analysis of borehole columns, seismic sections and HEM, a hydrogeological model is set up. The groundwater model is developed using the finite-element programme FEFLOW. The density dependent groundwater model is calibrated on the basis of hydraulic, hydrological and geophysical data, in particular spatial HEM and local monitoring data. Verification runs with the calibrated model show good agreement between measured and computed hydraulic heads. A good agreement is also obtained between measured and computed density or total dissolved solids data for both the entire freshwater lens on a large scale and in the area of the well fields on a small scale.

For simulating future changes in this coastal groundwater system until the end of the current century, we use the climate scenario A2, specified by the Intergovernmental Panel on Climate Change and, in particular, the data for the German North Sea coast. Simulation runs show proceeding salinisation with time beneath the well fields of the two waterworks Waterdelle and Ostland.
\end{abstract}

The modelling study shows that the spreading of well fields is an appropriate protection measure against excessive salinisation of the water supply until the end of the current century.

\section{Introduction}

Investigation of the impact of climate change and the resulting sea level rise on the freshwater resources of the southern North Sea Region including the Danish coastal area (North and western Baltic Sea) is aim of the Interreg project CLIWAT (http://www.cliwat.eu). In particular, the drinking water resources of barrier islands like the German North Sea Island of Borkum (Fig. 1) are endangered by enhanced sea water intrusion and enhanced upconing of sea water in the vicinity of the water supply well fields. Vulnerable areas have to be identified and mitigation measures need to be defined and adopted.

The future development of the salinity distribution in the subsurface can be simulated using a numerical density dependent groundwater flow model (e.g., Oude Essink et al., 2010). Numerous density dependent groundwater models have been developed in the last decades (de Louw et al., 2011; Post and Abarca, 2010; Post, 2005; Thorenz, 2001; Bear et al., 1999; Holzbecher, 1998; Lee and Cheng, 1974; Cooper et al., 1964). However, most of these applications are afflicted with a poor database of field data. In particular, depth-dependent densities, which are composed mainly of 

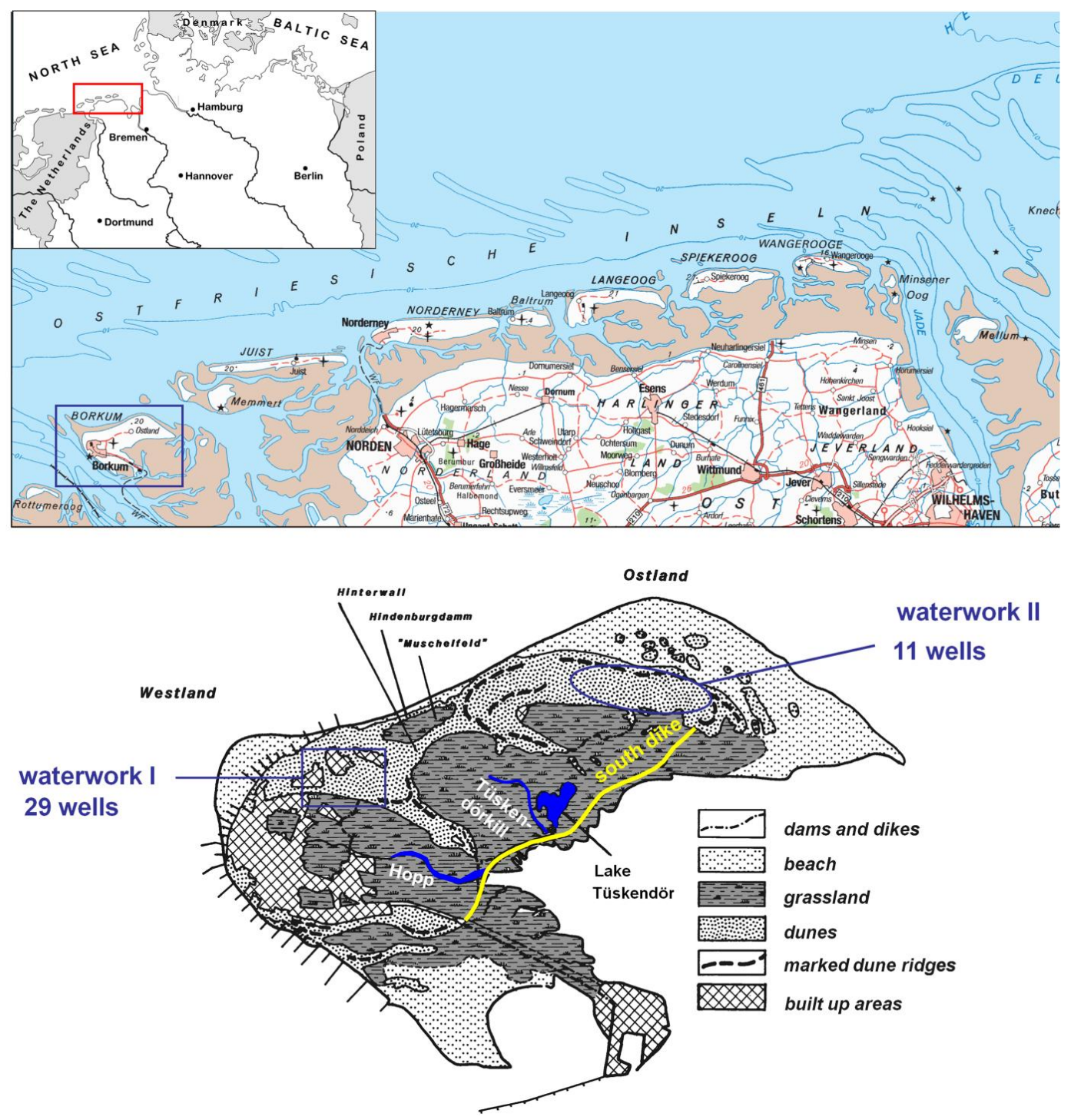

Fig. 1. Top panel: location map of study area, bottom panel: North Sea Island of Borkum with its two waterworks (WW): WW I Waterdelle and WW II Ostland and the two major rivers.

sea salt or comprehensive data of chloride distribution covering the total modelling area, are often missing.

Nevertheless, a good database is required to calibrate a groundwater model capable of a reliable forecast. Recent geophysical techniques, e.g., helicopter-borne electromagnetic (HEM) surveys (Siemon et al., 2009b) and real time electrical data, monitored via vertical electrode chains in boreholes (Grinat et al., 2010), are essential for the calibration of groundwater models using density data.

The groundwater model for Borkum has been set up utilising the finite-element programme FEFLOW ${ }^{\circledR}$ (http://www. feflow.de). A comprehensive database of hydraulic, hydrological and geophysical field measurements, mainly obtained in the time period from 2008 to 2010 , constitutes the basic data used for the model setup.
Great attention was paid to the model calibration, which is highly critical for the prognosis capability and the prognosis accuracy of the model. The focus of this work is essentially on the calibration process, particularly the density (or mass) calibration. New methods that enable the inclusion of the comprehensive geophysical database into the calibration procedure are presented in this study.

For model simulations of future changes in this coastal groundwater system until the year 2100 we use the A2 climate scenario from the Intergovernmental Panel on Climate Change IPCC (IPCC, 2007). Proceeding investigations and estimations suggest saltwater intrusion particularly around the waterworks until the end of this century caused by climate change and overexploitation. Making use of the numerical model as management tool it is demonstrated how 
mitigation measures at the well field configuration ensure sufficient water quality until 2100 without the need of reducing the wells production rates.

The freshwater lenses of the German East Frisian barrier islands have been in the focus of water supplier and research since Herzberg (1901) discovered here that the depth of the freshwater-saltwater interface in coastal aquifers is proportional to the elevation of the water table above sea level. Some modelling studies were done on neighbouring islands to Borkum (Fein et al., 2008; Petersen et al., 2003) but our work is the first study comprising the entire groundwater body (flow and density) of a German Wadden Sea island.

The present study has two major goals. The first one is to illustrate the geophysical and hydrological methods and how they contribute to develop a density dependent numerical model. The second one is to describe the simulation results with respect to the impact of climate change.

\section{Geological background and groundwater situation}

The southern North Sea coast developed after the last glaciations in the Holocene. With rising sea level the North Sea expanded to the south. Today's coastline was nearly reached about $6000 \mathrm{BC}$. After that time sea level rising diminished and the interplay of transgression and regression developed the barrier islands (Behre, 2008). The East Frisian Islands are dune islands and presumably younger than $2000 \mathrm{yr}$. Borkum is the westernmost and largest of these German islands, stretching $10 \mathrm{~km}$ from east to west and up to $7 \mathrm{~km}$ from north to south. It covers an area of about $31 \mathrm{~km}^{2}$. It is a typical barrier island with dunes to the sea side and a low-lying marshland area located to the mainland side (Streif, 1990).

The settlement and low-lying meadows in the centre of the island are protected by the great south dike and to the north by a belt of dunes ranging up to $21 \mathrm{~m}$. The southern dike was built in 1934 to prevent the meadows and marshland of central Borkum from regularly flooding during high tide. Before construction of the dike, the island consisted more or less of two main parts.

The drinking water supply of Borkum is autonomous and there are two waterworks (WW) (Fig. 1). The 29 wells of WW I (Waterdelle), located in the western part, reach down to a depth of $9 \mathrm{~m}$ and the 11 wells of WW II (Ostland), located in the eastern part, reach a depth of $41 \mathrm{~m}$ below surface. WW I started water abstraction in 1900 and WW II in 1965. From WW I an average amount of $340000 \mathrm{~m}^{3} \mathrm{a}^{-1}$ drinking water is delivered $\left(400000 \mathrm{~m}^{3} \mathrm{a}^{-1}\right.$ are permitted by the authorities) and from WW II an average amount of $530000 \mathrm{~m}^{3} \mathrm{a}^{-1}$ (permitted is $900000 \mathrm{~m}^{3} \mathrm{a}^{-1}$ ) (Fig. 2, top panel). According to the seasonal pattern of the tourism, the annual variation of the abstraction is considerable (Fig. 2, bottom panel) and varies usually during one year between 30000 and $125000 \mathrm{~m}^{3} \mathrm{month}^{-1}$ for all supply wells (Winter, 2008a, 2009) (Fig. 2, bottom panel). In general, the delivered water is of good quality and the chloride concentration in all wells is lower than $100 \mathrm{mg} \mathrm{l}^{-1}$. However, high concentrations of iron occur in several wells. After delivery the water has to be treated by standard procedures.

Historical maps and archive reports show that prior to the construction of WW I at the beginning of the last century the freshwater lens of Borkum had been in a steady state. Hydrological milestones in the history of Borkum were the start of drinking water abstraction at WW I, the construction of the great south dike, and the initiation of operation of WW II.

Recent studies (Winter, 2008a, 2009) indicate a limited fresh groundwater resource and a level of water abstraction that is just in balance with the amount of recharge. Climate changes are expected to adversely affect this balance in future and decrease the potential freshwater supply by salinisation although increasing precipitation on the island will partly counteract this development. A similar result was obtained by numerical simulations on a small island in the Baltic Sea (Rasmussen et al., 2012).

\section{Material and methods}

\subsection{Mapping the freshwater lens and the geological environment}

\subsubsection{Geological, hydrogeological and hydrological measurements}

For the geologic model a database with 381 boreholes was available from the Geological Survey of Lower Saxony (Landesamt für Bergbau, Energie und Geologie, LBEG). Most of them (350) were shallower than $40 \mathrm{~m}, 256$ even shallower than $20 \mathrm{~m}$. Only eight reached 70 to $80 \mathrm{~m}$ and were restricted to the water supply area Ostland. Five offshore boreholes were more than $3000 \mathrm{~m}$ deep, but with only poor information for the first hundred metres. Generally, at Borkum the base of Holocene fine sediments is found at a depth of about $10 \mathrm{~m}$ b.m.s.l. (below mean sea level) (Streif, 1990), and the base of Quaternary at about $-50 \mathrm{~mm}$.s.l. (LBEG database, http://nibis.lbeg.de/cardomap3/). At greater depth a salt structure has pierced Tertiary sediments. The top of this salt structure is found at $-500 \mathrm{~m}$ m.s.l. (Streif, 1990).

Topographic data of the whole Island of Borkum were taken from the dgm5 ATKIS model (Digitale Geländemodelle - DGM - ATKIS, LGN Niedersachsen). The data are gridded on a rectangular $12.5 \mathrm{~m} \times 12.5 \mathrm{~m}$ grid and exhibit a resolution of better than $\pm 0.5 \mathrm{~m}$ in horizontal and vertical direction.

Long-term average data of the groundwater recharge were obtained from the LBEG map-server (model GROWA06V2 1961-90). The maximum recharge of $300 \mathrm{~mm} \mathrm{a}^{-1}$ occurs in the area of the dune belt, whereas in the marshlands values below $50 \mathrm{~mm} \mathrm{a}^{-1}$ are found. Here, silt and clay predominate near the surface of the terrain 

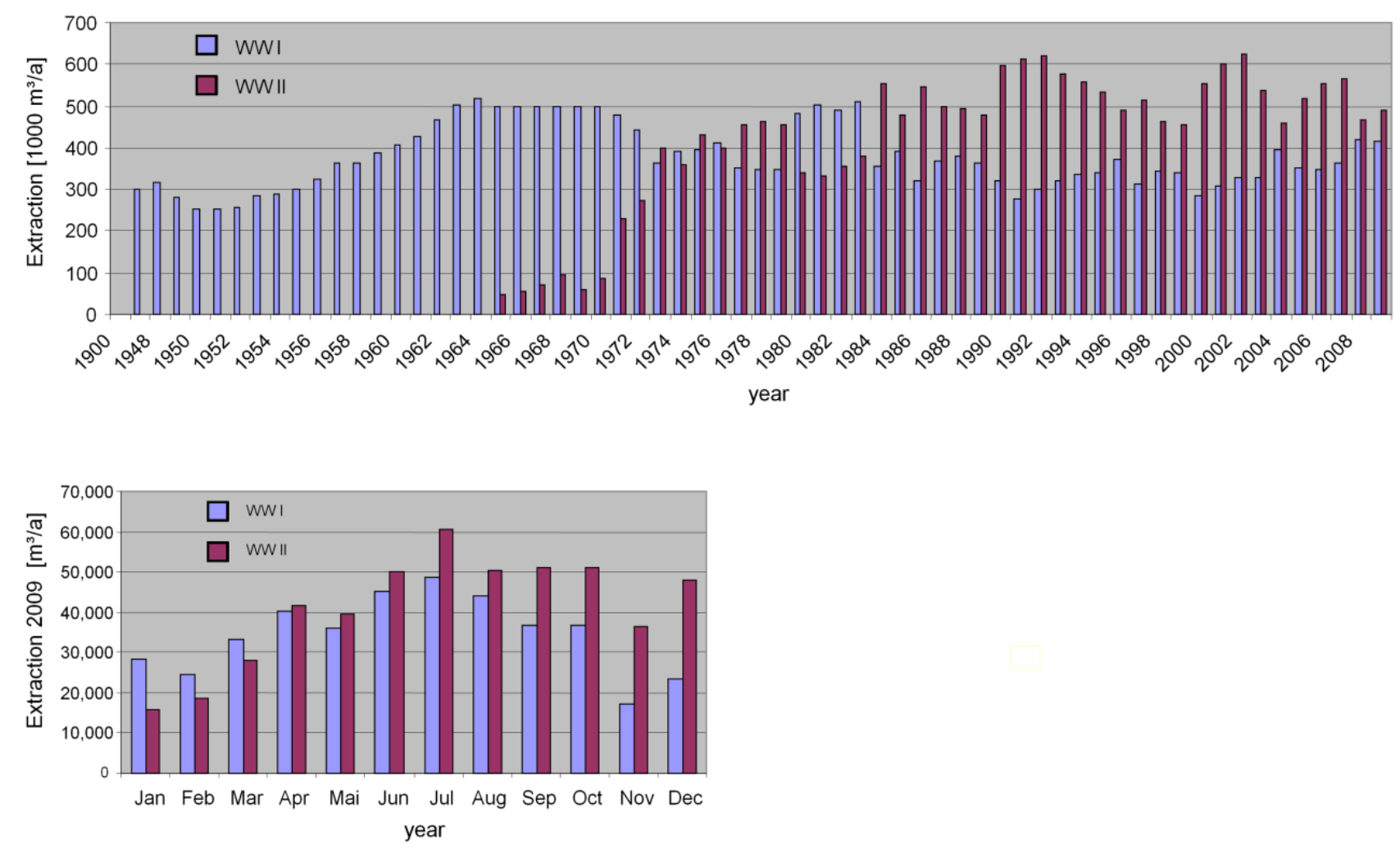

Fig. 2. Top panel: Annual delivery rates [1000 $\mathrm{m}^{3} \mathrm{a}^{-1}$ ] for WW I (Waterdelle), blue bars, and WW II (Ostland), dark red bars, bottom panel: monthly delivery rates for 2009 .

and most of the precipitation is drained before reaching the ground water table.

Historical data of the well field abstractions from the beginning of the delivery in 1900 until March 2010 were obtained from the local drinking water supplier.

In order to get a better understanding of the hydraulic composition of the aquifer, a series of 12 pumping tests was carried out all over the island in March and September 2009. Transmissivities are computed and summarised in Table 1. According to the configuration of the respective pumping test for all locations of the loggers in the draw down area, with $2,5,10 \mathrm{~m}$ (and so on) distance to the pumping location, transmissivities $T(2 \mathrm{~m}), T(5 \mathrm{~m}), T(10 \mathrm{~m})$ (and so on) were computed and averaged to one transmissivity $T$ at the pumping location. In addition, hydraulic conductivities on three vertical profiles were available from slug tests. Results and methods of pumping and mini slug tests are described and discussed in detail by Sulzbacher (2011). The mini slug test method is described by Hinsby et al. (1992).

Although the local drinking water supplier, the Stadtwerke Borkum GmbH, operates a network of more than 100 permanent groundwater observation wells, these are located more or less inside or close to the catchment areas of the well field WW I and WW II. Due to the lack of water table measurements covering the whole island, a comprehensive geodetic field campaign was carried out in June 2009 (133 altitude measurements at the groundwater table including levels of open water such as lakes, rivers, creeks, canals and drainage ditches).

In March 2010156 groundwater and open water level measurements were carried out. For this purpose holes were drilled down to the groundwater level by means of a hand auger drill in areas with poor information of the groundwater table. The altitude measurements of the groundwater table were carried out with high precision Trimble GPS equipment. The altitude accuracy of these data is up to $\pm 6 \mathrm{~cm}$. For the hydraulic calibration at reference time (March 2010), overall 258 reference date measurements of the groundwater level were available. The altitude of the groundwater table of the upper aquifer varies from about $0 \mathrm{~m}$ in the marshland behind the great south dike and meadows to about $+3.5 \mathrm{~m}$ m.s.l. in the dune areas (Fig. 3).

During February 2008, Direct Push vertical soundings were conducted on Borkum near and directly on the freshto-salt interface by GEOLOG GmbH on behalf of the water supplier (Winter, 2008b). The data were used to investigate the progressing salinisation of the groundwater caused by a storm flood in the course of the winter storm Kyrill in January 2007. The soundings deliver vertical profiles where the electrical conductivity of the "non-saturated" and saturated 
Table 1. Transmissivity ( $T$ ) obtained from pumping tests. According to the configuration of the pumping test for all locations of the loggers in the draw down area with 2, 5, $10 \mathrm{~m}$ (and so on) distance to the pumping location, transmissivities $T(2 \mathrm{~m}), T(5 \mathrm{~m}), T(10 \mathrm{~m})$ (and so on) were computed and averaged to one transmissivity $T$ at the pumping location.

\begin{tabular}{|c|c|c|c|c|c|c|c|c|}
\hline No. & $T(2 \mathrm{~m})$ & $T(5 \mathrm{~m})$ & $T(10 \mathrm{~m})$ & $T(20 \mathrm{~m})$ & $T(100 \mathrm{~m})$ & pumped aquifer & $T\left[\mathrm{~m}^{2} \mathrm{~s}^{-1}\right]$ & location \\
\hline P01 & $4.61 \mathrm{E}-4$ & $5.50 \mathrm{E}-4$ & $5.60 \mathrm{E}-4$ & & & 1 & $5.24 \mathrm{E}-4$ & Horse Pasture \\
\hline P02 & & $5.48 \mathrm{E}-4$ & $4.28 \mathrm{E}-4$ & $6.04 \mathrm{E}-4$ & & 1 & $5.39 \mathrm{E}-4$ & Fish Pond \\
\hline $\mathrm{P} 03$ & $2.07 \mathrm{E}-3$ & $2.05 \mathrm{E}-3$ & $2.54 \mathrm{E}-3$ & $2.43 \mathrm{E}-3$ & $2.39 \mathrm{E}-3$ & 1 & $2.03 \mathrm{E}-3$ & Sewage \\
\hline P04 & & $2.18 \mathrm{E}-3$ & $2.63 \mathrm{E}-3$ & $2.76 \mathrm{E}-3$ & & 1 & $1.89 \mathrm{E}-3$ & Land Fill \\
\hline P05 & & $2.64 \mathrm{E}-3$ & $3.10 \mathrm{E}-3$ & & & 1 & $2.87 \mathrm{E}-3$ & South East Dunes \\
\hline P06 & & $5.0 \mathrm{E}-3$ & $5.30 \mathrm{E}-3$ & $5.12 \mathrm{E}-3$ & $6.80 \mathrm{E}-3$ & 1 & $5.56 \mathrm{E}-3$ & North Beach \\
\hline P07 & $1.00 \mathrm{E}-3$ & $1.09 \mathrm{E}-3$ & $1.39 \mathrm{E}-3$ & $2.30 \mathrm{E}-3$ & & 1 & $1.45 \mathrm{E}-3$ & Bantje-Dunes \\
\hline P08 & $2.29 \mathrm{E}-3$ & $1.47 \mathrm{E}-3$ & $1.44 \mathrm{E}-3$ & $2.78 \mathrm{E}-3$ & $1.61 \mathrm{E}-3$ & 1 & $1.92 \mathrm{E}-3$ & Lake Tüskendör \\
\hline P-OD22 & \multicolumn{7}{|c|}{ no draw down recognized } & Dunes Ostland \\
\hline P-OD33 & & $6.37 \mathrm{E}-4$ & $6.38 \mathrm{E}-4$ & & & 1 & $6.38 \mathrm{E}-4$ & Dunes Ostland \\
\hline P-OD35 & \multicolumn{5}{|c|}{$\begin{array}{l}\text { disturbed by tidal fluctuations, evaluation of draw } \\
\text { downs not possible, no draw downs in aquifer } 1\end{array}$} & 2 & & Kobbe-Dunes \\
\hline P-Br38a & \multicolumn{5}{|c|}{$2.50 \mathrm{E}-3$ (CLIWAT-IIa), 1.90E-3 (OD8) } & 1 & $2.20 \mathrm{E}-3$ & Ostbake \\
\hline P-Br38b & \multicolumn{5}{|c|}{ 2.00E-3 (CLIWAT-IIb), 2.19E-3 (OD8) } & 2 & $2.10 \mathrm{E}-3$ & Ostbake \\
\hline
\end{tabular}

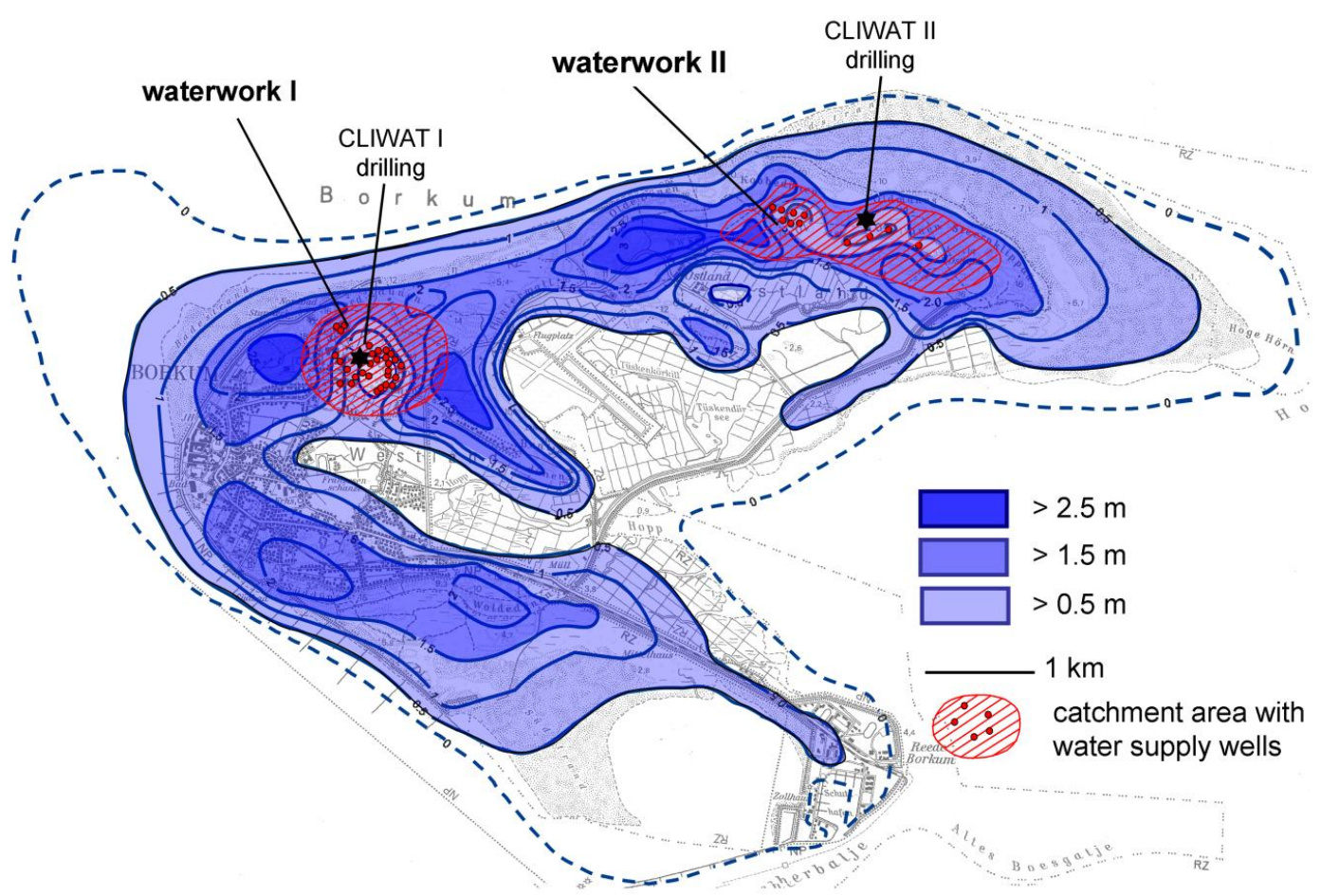

Fig. 3. Groundwater table of the upper aquifer during March 2010 (water supply wells marked by red circles, location of CLIWAT drillings marked by black stars, mean sea level marked by dashed line).

sediments was recorded continuously down to a depth of usually $15-25 \mathrm{~m} .41$ of these vertical profiles were performed across the border of the freshwater lens in the vicinity of WW I and II. Additionally, several in situ measurements of the electrical conductivity from water samples were taken from nearly all of these vertical profiles. The water samples can be compared with computed pore water electrical conductivities at the same temperature for model verification.
Runoff measurements from the open water system, available from field work carried out on Borkum 2009 and 2010, were included in the hydraulic calibration procedure. The measurements were carried out systematically at rivers Hopp and Tüskendörkill (Fig. 1), covering nearly the whole catchment area of open water on the island (Sulzbacher, 2011).

Simultaneously to the groundwater level measurements water electrical conductivity values were gauged at the 


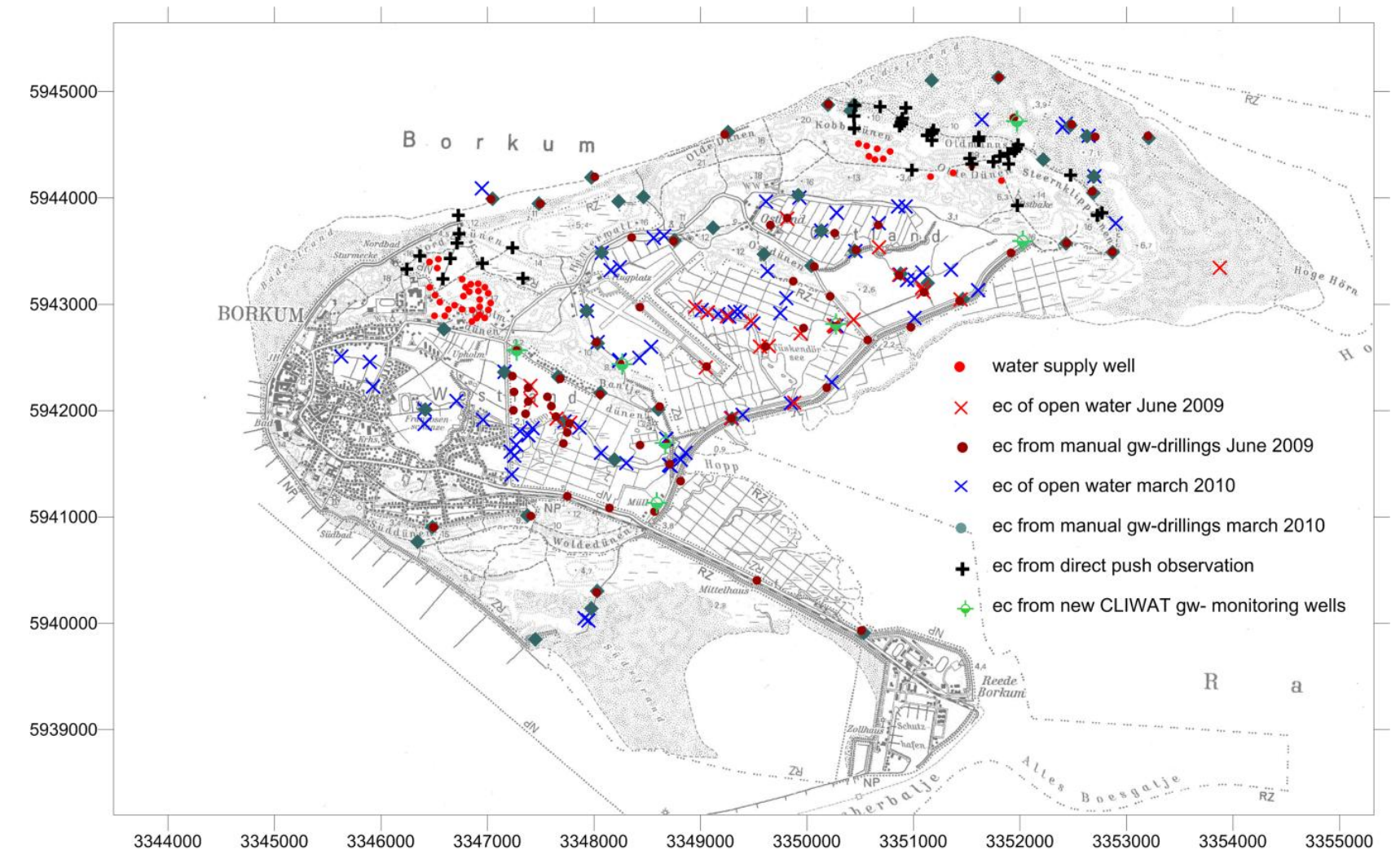

Fig. 4. Observation points of electrical water conductivity (ec) and temperature at the surface of the groundwater table during June 2009 and March 2010, all 260 locations are represented.

surface of the groundwater table and open water in June 2009 and March 2010. Including 41 Direct Push samples overall 260 values of the pore water conductivity were obtained. Figure 4 shows locations, sampling type and time of these measurements (Sulzbacher, 2011).

\subsubsection{Geophysical methods}

An excellent overview of the spatial distribution of the electrical conductivity was provided by a helicopter-borne electromagnetic survey carried out by the German Federal Institute for Geosciences and Natural Resources (BGR, Hannover) in March 2008 (Siemon et al., 2009a). The entire island and parts of the adjacent Wadden Sea were covered by $35 \mathrm{NW}-\mathrm{SE}$ lines with $250 \mathrm{~m}$ spacing and $11 \mathrm{SW}-\mathrm{NE}$ tie lines with $500 \mathrm{~m}$ spacing. In total 550 line-km were flown covering an area of $75 \mathrm{~km}^{2}$. From these HEM data smooth electrical conductivity models with 15 layers were derived (Siemon et al., 2009b) and displayed as conductivities at several depths below sea level which clearly show the spatial variation of the freshwater lens (Fig. 5).

Two new drillings together with geophysical logging were established in 2009: CLIWAT I located in Waterdelle, $67 \mathrm{~m}$ deep, and CLIWAT II in Ostland, $77 \mathrm{~m}$ deep (Fig. 3). Two vertical electrode chains have been installed in the transition zone from freshwater to saltwater at a depth between 45 and $65 \mathrm{~m}$ to monitor the spatiotemporal behaviour of the electrical conductivity of the saturated sediments with a sampling interval of $5 \mathrm{~h}$ (Südekum et al., 2009; Grinat et al., 2010).

As the information on the deeper subsurface is relatively poor, we measured a $0.5 \mathrm{~km}$ long high-resolution seismic reflection profile with $\mathrm{P}$-waves as well as with $\mathrm{S}$-waves. As seismic source we used the electrodynamic vibrator system ELVIS (Polom et al., 2011; Krawczyk et al., 2012). We reached a depth of $300 \mathrm{~m}$ with P-waves and about $50 \mathrm{~m}$ with S-waves.

In the north-east, north and north-west part of the island, the near surface was also investigated by ground-penetrating radar (GPR) with a total of $20 \mathrm{~km}$ constant-offset profiles measured in September 2009. The elevation of the groundwater table was mapped on most of the profiles and is in good accordance with the groundwater monitoring measurements and hand drillings in the region. A sharp and strong horizontal reflection at a depth of $-0.5 \mathrm{~m}$ to $1 \mathrm{~m}$ m.s.l. can be seen on most of the profiles and was identified as a $0.20 \mathrm{~m}$ thick silt loam layer by hand drillings (Igel et al., 2012).

Magnetic resonance soundings (MRS) are capable of obtaining a model of water content (porosity) and decay time as a function of depth. Both are related to the hydraulic conductivity of the aquifer and can, after calibration, provide 


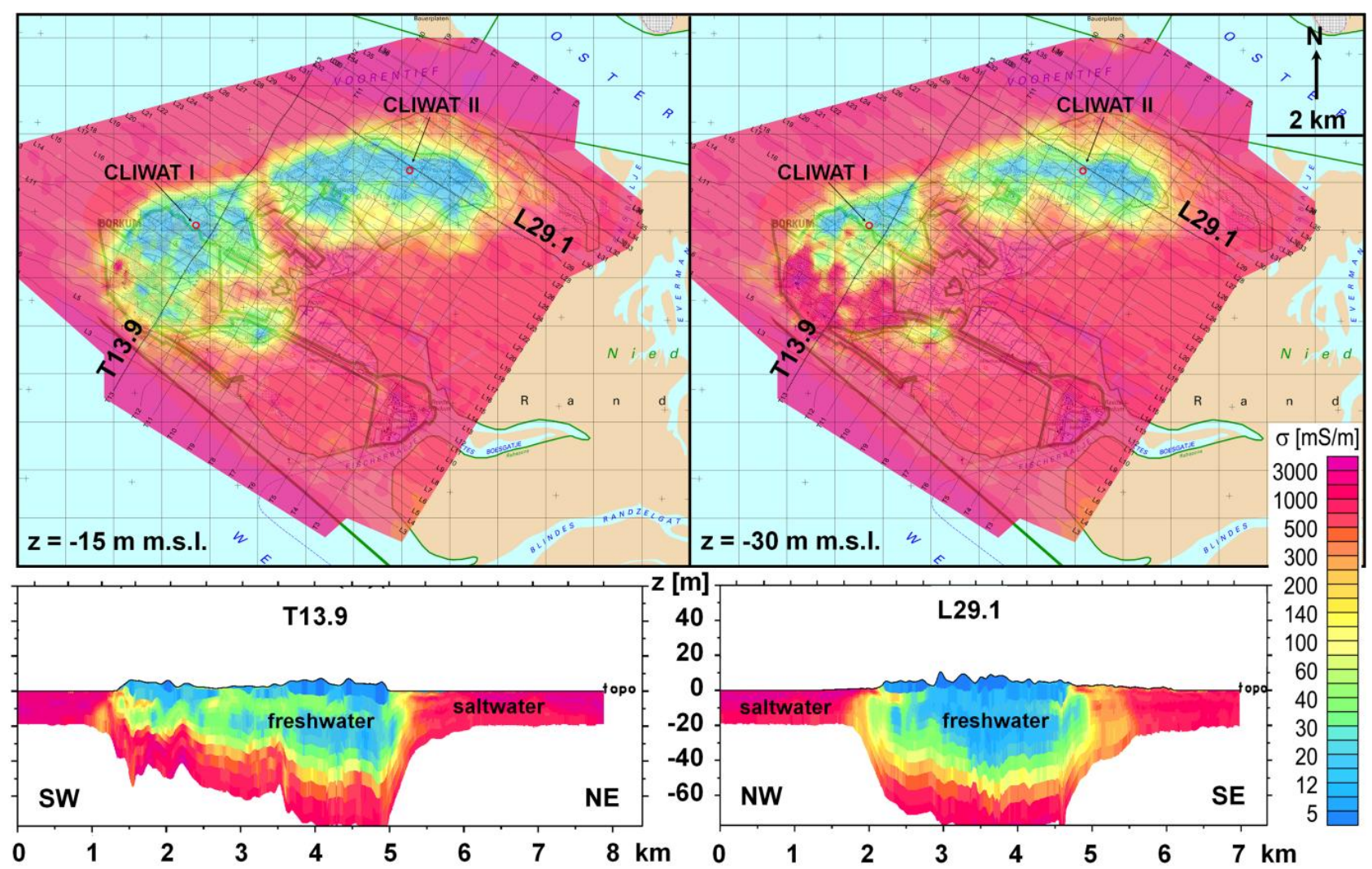

Fig. 5. Top panel: Electrical conductivity $(\sigma)$ maps at different depths derived from helicopter-borne electromagnetic survey, bottom panel: cross sectional view along transects T13.9 and L29.1.

non-invasive estimates of the hydraulic parameters (Günther and Müller-Petke, 2012). In a preliminary study, four soundings have been carried out, one of them at the CLIWAT II borehole and one at an existing well. Results of pumping tests P-Br38a and P-Br38b, carried out near the CLIWATII drilling, as well as pumping test P-OD33 were used to achieve calibration. The measurements were jointly inverted with vertical electrical soundings. As a result, lithology can be differentiated from salinity and total dissolved solids (TDS) concentrations as well as sediment porosities can be predicted (Günther and Müller-Petke, 2012). However, due to the extremely limited data, the results were solely used for corroboration of the model results. A comparison shows remarkably good agreement with the hydraulic model.

\subsection{Surface mass concentration map}

As the accuracy of the density distribution at the model top surface is essential for the precision of the prognosis simulations (Sect. 6) it is described in more detail in the following. HEM data are of great importance for the construction of mass transport boundary conditions at the surface of the aquifer.

As a first step the different measurements of electrical conductivity need to be adjusted concerning temperature, which was measured in situ together with the electrical conductivities at the water table. During March 2008, when the HEM survey was performed, average aquifer temperature and temperature of the sea water close to the surface amounted to approximately $5^{\circ} \mathrm{C}$ (BSH, 2009). Because electrical conductivities strongly depend on temperature and rise by about $4 \% / 1{ }^{\circ} \mathrm{C}$, pore water electrical conductivities of manual measurements at the surface of the groundwater table as well as Direct Push and laboratory water analysis had to be transferred into values referring to $5^{\circ} \mathrm{C}$.

In this way, it is possible to compare later the computed with the measured pore water densities which is necessary to verify the calibrated model.

The second step is to regionalise the measured pore water conductivity data at the surface of the aquifer (Fig. 4). We do this with the help of the HEM data. Therefore, we define the ratio of the pore water conductivity $\sigma_{\mathrm{w}}$ and the conductivity of the saturated sediments $\sigma_{\mathrm{b}}$, measured by geophysical methods like HEM as $F_{\mathrm{a}}=\sigma_{\mathrm{w}} / \sigma_{\mathrm{b}}$. In the literature $F_{\mathrm{a}}$ is known as apparent formation factor (Katsube et al., 2000; Repsold, 1990). It should be emphasized, however, that this factor is used here for the regionalisation of the surface electric conductivity data regardless of its hydrogeological meaning. 


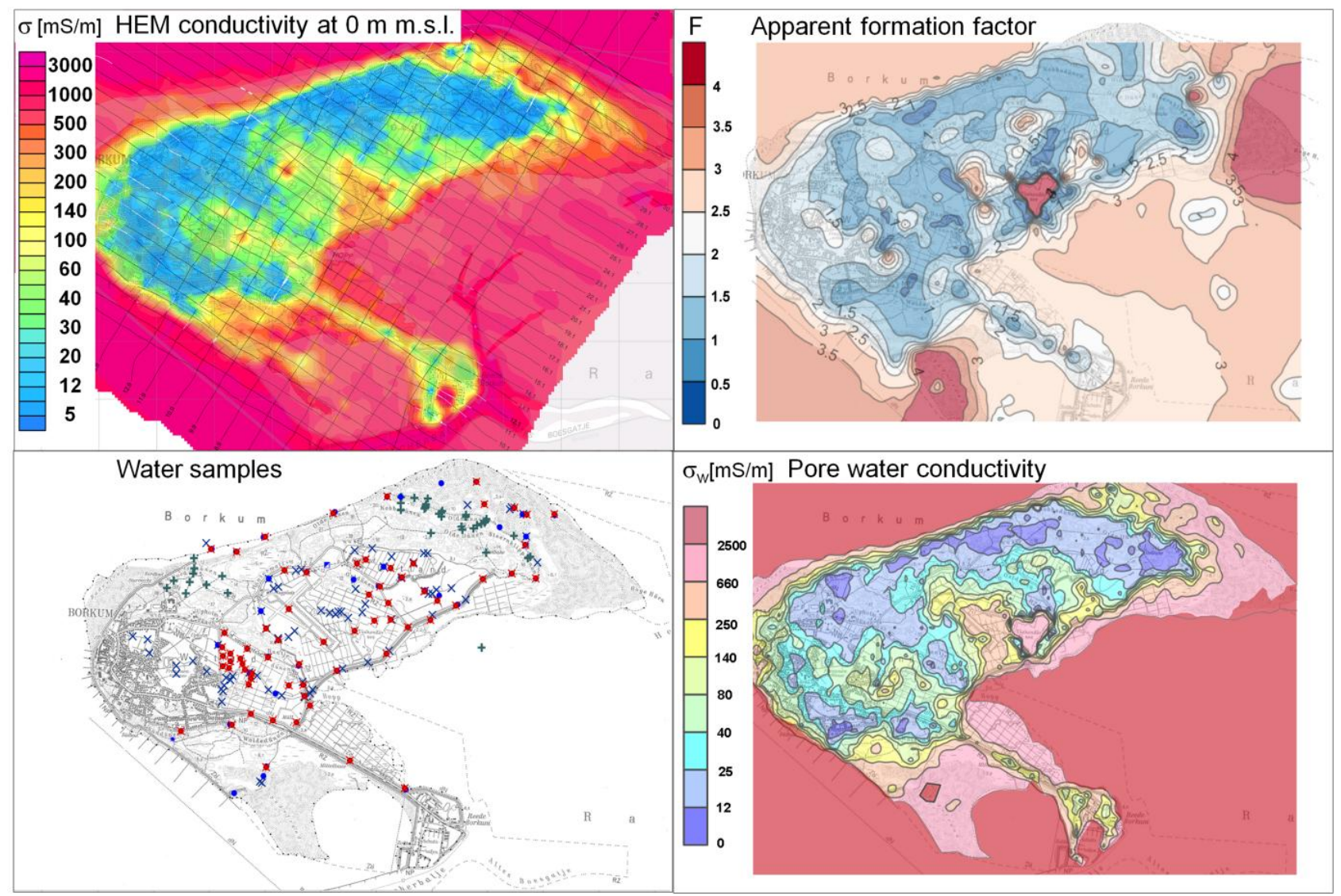

Fig. 6. Regionalisation of electrical conductivity data at the water table by means of data from helicopter-borne electromagnetics (HEM) and apparent formation factors. Top left panel: electrical conductivities at $0 \mathrm{~mm}$.s.l. from HEM, (bottom left panel) locations of electrical conductivity from manual readings at the water table (see Fig. 4), top right panel: apparent formation factors at the water table, bottom right panel: regionalised conductivity map at the surface of the groundwater table.

Moreover, HEM electrical conductivities according to an aquifer depth of $0 \mathrm{~mm}$.s.l. are assumed to be the same electrical conductivities than those of the aquifer at the surface of the groundwater table. The cross-sections of Fig. 5 show the validity of this approximation. $F_{\mathrm{a}}$ can now be computed from the individually measured pore water conductivity data $\sigma_{\mathrm{w}}$ (Fig. 6, bottom left panel) and $\sigma_{\mathrm{b}}$ measured by HEM (Fig. 6, top left panel) at the same locations at the surface of the groundwater table.

Inside the island, in particular inside the area of the freshwater lens, the calculated values of $F_{\mathrm{a}}$ vary relatively weakly in the range of about 1-2 (average value: 1.53, aquifer: 0.95 , open water: 2.29) which means that the pore water exhibits approximately the same electrical conductivity as the conductivity of the saturated sediments obtained from HEM data at these locations (see Sulzbacher, 2011). The relatively low apparent formation factors at the surface of the aquifer are due to the fact that the near-surface layer exhibits high content of cohesive material like silt and clay, which is confirmed by the statistical analysis of the drilling results (see Sect. 4, Fig. 7, left panel). Low apparent formation factors in the same order of magnitude have also been observed in wide areas of the marshlands of the German North Sea coast (Repsold, 1990) or in the area of the Belgium and Dutch North Sea coast (Geirnaert and Vandenberghe, 1988; van Overmeeren et al., 1991; TNO-IGG, 1992).

Due to the approximately seasonal stability of the salinity of the aquifer at the surface, at least beside the open water, all data from both campaigns June 2009 and March 2010 were used for the construction of a contour map of the electrical conductivity. Although intensive sampling on the surface of the aquifer was conducted, data coverage was not dense enough and the variation of the measured values was too high for a reliable regionalisation of the data with a contouring algorithm in areas with low data coverage. Instead, it is possible to interpolate the relatively low varying formation factors in a reliable way with a Kriging algorithm as shown in Fig. 6 (top right panel). Offshore sea water conductivity at $5^{\circ} \mathrm{C}$ is assumed to be $3120 \mathrm{mS} \mathrm{m}^{-1}$ according to TDS of $35000 \mathrm{mg} \mathrm{l}^{-1}$, the mean salinity of the North Sea (e.g., Heyen and Dippner, 1998). Manual measurements of the electrical conductivity at the sea water near the shore of 


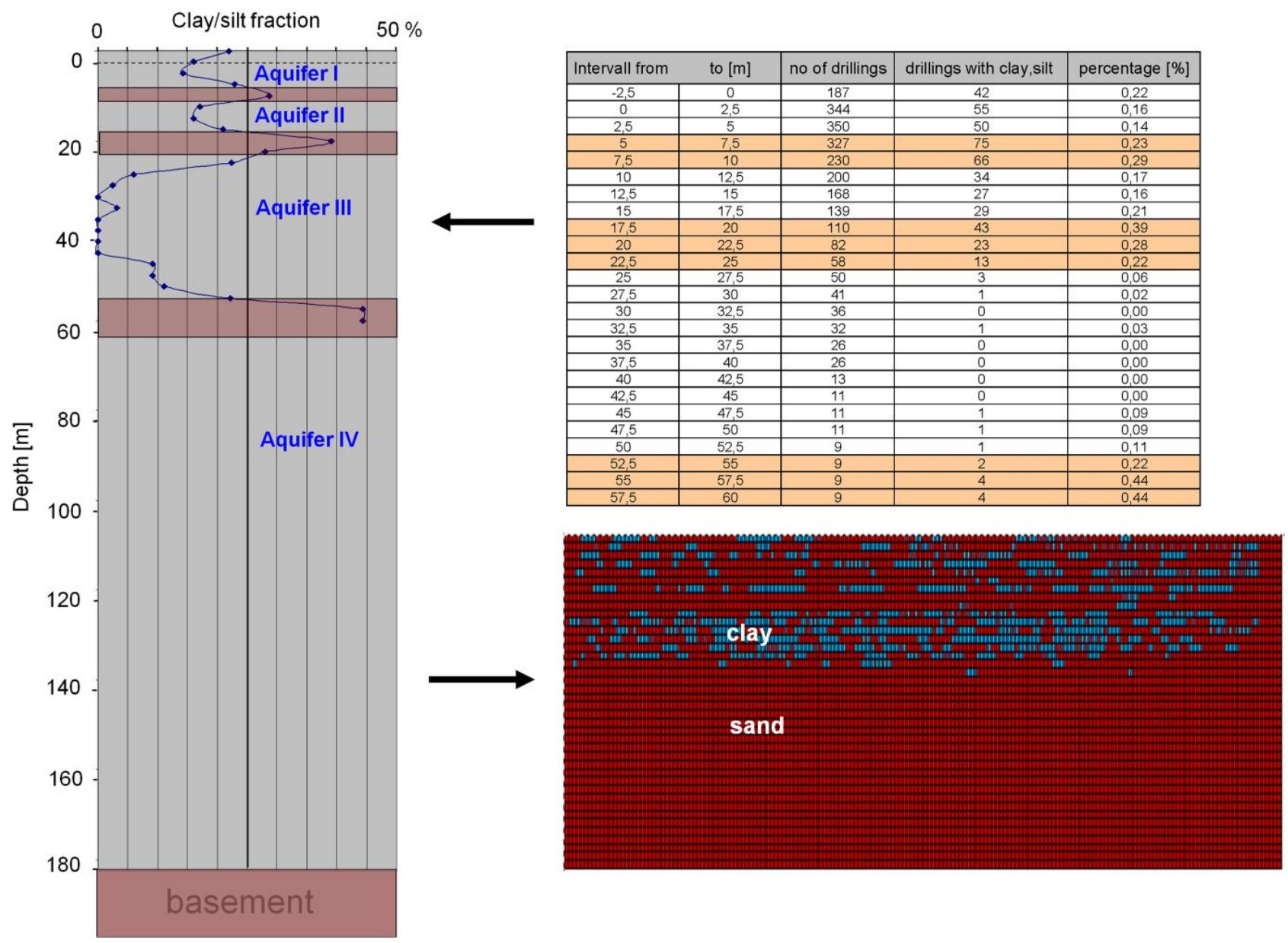

Fig. 7. Left panel: statistical evaluation of drillings and hydrogeological model, (top right panel) data values, (bottom right panel) schematic cross-section of the aquifer for two dimensional numerical simulations.

Borkum and the analysis of sea water samples in the laboratory at Geozentrum in Hannover show that this is approximately the case, also in the Wadden Sea around Borkum. Submarine fresh water breakouts from the aquifer, therefore, play a negligible role.

To obtain supporting points for the sea region, additional apparent formation factors were gained by dividing sea water electrical conductivity by the corresponding HEM conductivity.

Figure 6 (top left panel) shows that HEM electrical conductivities in shallow sea water are considerably influenced by the sediments of the sea bottom beneath shallow sea water, particularly in the Wadden Sea. Electrical conductivities conductivities in these areas are only a fraction of those values typical for sea water, wherefore apparent formation factors in this region are considerably greater than the theoretical value of 1 as shown in Fig. 6 (top right panel).

In a next step all values of HEM electrical conductivity at depth $0 \mathrm{~m}$ and computed on a $69 \times 100$ grid (Fig. 6, top left panel) are multiplied cell by cell with formation factors $F_{\mathrm{a}}$ on the same grid (Fig. 6, top right panel) to obtain the desired pore water conductivities (Fig. 6, bottom right panel). The figure shows contour lines and fringes of the electrical conductivity at the water table referring to water temperatures of $5^{\circ} \mathrm{C}$. It is a map of measured pore water conductivities interpolated and extrapolated with information obtained by HEM measurements.

The last step is to transfer these conductivity values into TDS values by multiplying all of them with a constant, temperature-dependent factor $M$. In total 124 water samples analyses were conducted from sea water at different locations, from water supply wells, new drillings or $\mathrm{Di}-$ rect Push measurements and evaluated in the laboratory at Geozentrum in Hannover. From electric conductivities at $5^{\circ} \mathrm{C}$ and TDS values, the dimensionless factor $M$ was determined. For water temperatures of $5^{\circ} \mathrm{C}$ and typical sea water, $\mathrm{NaCl}$-dominated brackish or $\mathrm{NaCl}$ contaminated freshwater it amounts to $M=11.23$, valid for $\sigma$ given in $\mathrm{mS} \mathrm{m}^{-1}$ and the TDS in $\mathrm{mg}^{-1}$. 

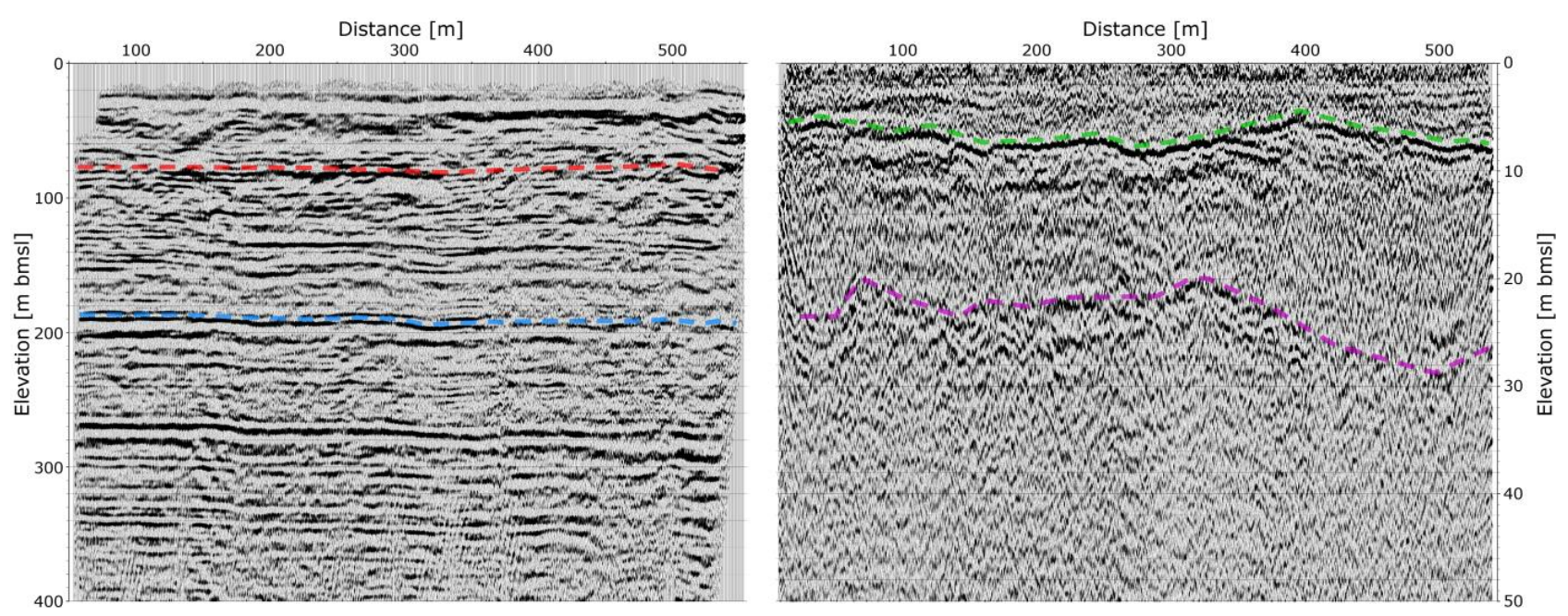

Fig. 8. Seismic results, (left panel) P-wave section, (right panel) S-wave section (note the different depth scales).

From TDS values, mass transport initial and boundary conditions at the surface are constructed for the current numerical model as described in Sect. 4.2.

\section{Model setup}

\subsection{Hydrogeological model setup}

For the setup of the hydrogeological model the borehole information was statistically analysed. In so doing, the aquifer was divided into depth intervals of $2.5 \mathrm{~m}$ and for each interval the number of drillings containing cohesive material, such as clay or silt, was set in relation to all drillings intersecting this interval (Fig. 7, right panel). The first of this interval is located $0-2.5 \mathrm{~mm}$.s.l., representing the freshwater lens above sea level and the last interval ends at $-180 \mathrm{~mm}$.s.l., at the bottom of the aquifer. The zones with high clay/silt fraction are regarded as aquitards. The evaluation result yields an aquifer roughly divided into four parts, each separated by more or less leaky aquitards. In the area of the water supply well fields, there are extended clay layers protecting the drinking water from pollution from above and upconing salt from below. The uppermost three Quaternary aquifers are used for drinking water supply and reach down to a depth of about $60 \mathrm{~m}$. It should be mentioned that there is only very poor information about the fourth aquifer.

The geological model, shown in Fig. 7 (left panel) is, of course, a rather simplified, schematic imagination. In reality, hydrogeological features are much more complex. In the numerical model (Sect. 5) the horizontal and vertical heterogeneity of hydrogeological parameters, like hydraulic conductivities and transmissivities, is implemented sufficiently close to reality to meet accuracy demands for the prognosis results (see Sects. 5 and 6). Further, as pointed out by
Voss (2011a,b), too many details do not necessarily improve the models prognosis capabilities.

Two-dimensional density dependent numerical model calculations with FEFLOW indicate that the aquitards consist of non-persistent cohesive material (predominantly clay, socalled patch rock), schematically shown in Fig. 7 (bottom right panel). The models were designed as vertical NW-SE cross sections through Borkums aquifer in the appropriate spatial dimension and set up with FEFLOW standard values for all parameters like hydraulic conductivity, porosity or specific yield.

This concept is supported by the results of the seismic reflection profile with P- and S-waves (Fig. 8). The distinct reflector at $180 \mathrm{~m}$ depth in the P-wave section marks the basement of the model. The Quaternary base, located at a depth of about $60 \mathrm{~m}$, separating the deepest aquifer IV from the aquifer III, is unequivocally shown in the same seismic section also as a significant reflector (Fig. 8, left panel). The aquitard, at a depth of about 20-25 m, separating aquifer III and aquifer II, can be observed in the P-wave section as first clearly observable reflector. The latter can be seen more clearly in the higher resolution S-wave section (Fig. 8, right panel). And the aquitard located at a depth of about 7-10 $\mathrm{m}$ can also be resolved in the seismic S-wave section as well as in the HEM data (shallow conductors in cross-sections of Fig. 5).

The results of the pumping tests are in accordance with this model concept. In particular the large transmissivities determined by the tests in the coastal region (P06 in Table 1) are in agreement with the idea of leaky or missing aquitards in this region as is demonstrated in Fig. 7 (bottom right panel). In the centre of the island the smaller transmissivities (P01, P02, P-OD33 in Table 1) suggest that layers separating the aquifers also act as hydraulic barriers and therefore exhibit rather the character of aquicludes (Sulzbacher, 2011). 


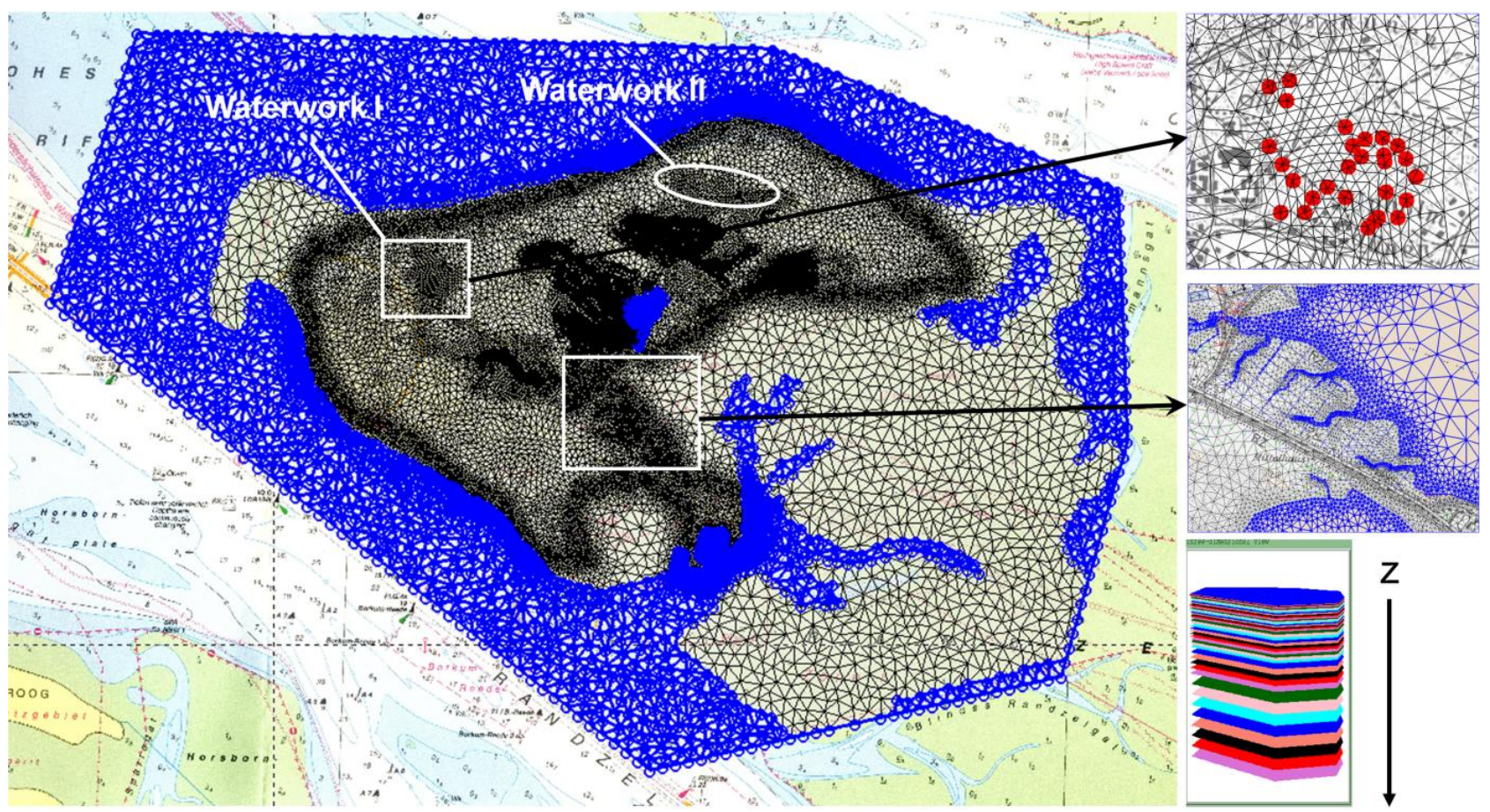

Fig. 9. Setup of the numerical model, left panel: horizontal discretisation and mass transport boundary conditions. The blue marked cells represent sea water boundary conditions at a depth of $1 \mathrm{~m}\left(\mathrm{TDS}=35000 \mathrm{mg} \mathrm{l}^{-1}\right)$, right panel: discretisation of model in areas with high complexity. The model consists of 39 superposed horizontal layers, downwards with increasing thickness with depth.

For the model setup it is important that in the Wadden Sea around Borkum the water depth everywhere is relatively shallow and amounts to only some metres or less below sea level, which can be seen in Fig. 9 (left panel). Here, the sea water at $1 \mathrm{~m}$ depth is marked with blue mass transport boundary conditions. It is obvious that the aquifer (not coloured) extends at this depth considerably beyond the shoreline of Borkum.

\subsection{Numerical model}

The setup of the three-dimensional numerical model with the finite element code FEFLOW is designed according to the hydrogeological model. The model area incorporates wide parts of the Wadden Sea and is approximately three times as large as the Island of Borkum itself (Fig. 9, left panel). The figure shows boundary conditions for the sea water - aquifer interface at $1 \mathrm{~m}$ depth (constant head and constant mass transport). It can be seen that this important "natural" boundary extends at low water depth over wide parts off the Island of Borkum, also beyond the borders of the modelling area. The correct location of the interface between aquifer and sea in the model is important with respect to the simulation accuracy and can be realised only by a large model area. This is necessary to guarantee that "artificial NoFlow" boundary conditions for flow and mass transport at the outer edge of the model do not affect model calibration and simulation results.
Due to numerical stability reasons and the need to resolve the hydrogeological layers and the vertical screens of the water supply wells of the waterworks, the model was set up with 39 horizontal layers (Fig. 9, right panel). A high degree of discretisation was chosen in order to assure numerical stability and to be able to resolve the network of open water and the complex course of the coast line also in horizontal direction (Fig. 9, right panel). In particular, this was necessary in areas where high gradients of freshwater-saltwater distribution were detected. Cell sizes down to $10 \mathrm{~m}$ were implemented in order to meet the Peclet's criterion for the maintenance of numerical stability (e.g., Kinzelbach, 1987). In outer regions of the Wadden Sea without significant flow a relative coarse net of cell sizes of about $200 \mathrm{~m}$ was used.

In all model layers at all depths the seawater was designed with constant head and constant mass transport boundary conditions of $35000 \mathrm{mg} \mathrm{l}^{-1}$, according to the average North Sea TDS concentration. Constant mass transport boundary conditions with values of the corresponding aquifer mass concentration, derived from surface conductivity measurements and HEM electrical conductivities, as described in Sect. 3.3, were assigned to the surface nodes of the groundwater table. In doing so, all processes of salinisation at the water table including spray salt, regular flooding by the sea, rain events or river upconing are taken into account. Together with precipitation, realized by the Neumann flux boundary conditions at the water table, the mass concentration flow 
Table 2. Fixed flow parameters.

\begin{tabular}{ll}
\hline $\mathrm{kf}_{x} / \mathrm{kf}_{y}\left[\mathrm{~m}^{2} \mathrm{~s}^{-1}\right]$ & 1 \\
Density ratio & 0.0270 \\
Specific yield [1] & 0.25 \\
Compressibility $\left[1 \mathrm{~m}^{-1}\right]$ & 0.001 \\
\hline
\end{tabular}

into the deeper aquifer is properly computed. This approach assumes that the TDS concentration at the water table is subjected to only small seasonal fluctuations, an assumption which is supported by the field measurements carried out on Borkum (Sect. 3.12).

Significant changes of the TDS concentrations at the water table, caused by important hydrological changes in the upper aquifer such as engineering constructions or sea level changes have to be implemented by a readjustment or time dependency of this kind of boundary condition in the model. This has been done for the construction of the great south dike in 1934 during model calibration (Sect. 5) and for the simulation of the climate scenarios (Sect. 6).

This method is common praxis in density dependent groundwater modelling, as documented in the technical reference manual of the modelling code by DHI WASY GmbH (2009).

The network of open water could be implemented by Cauchy boundary conditions, Lake Tüskendör and the lower reaches of the rivers Hopp and Tüskendörkill (Fig. 1) by constant head boundary condition (see Agmon et al., 1959; Bear et al., 1999 for a more detailed description of this technique).

On the whole, about 1.5 million triangular finite elements were necessary to construct the three dimensional finite elements grid. The upper limiting surface (slice) of the top layer is treated as topography. The aquifer is considered as unconfined where it is located beneath the top slice or treated as confined where it would be above. In areas above the free aquifer, an unsaturated zone has to be considered during simulation. The method as well as the used default parameters are described in the technical reference manual of the modelling code by DHI WASY GmbH (2009).

Fixed flow parameters which were used in the model for all 4 aquifers are summarised in Table 2. Hydraulic conductivities $k_{f}$ were determined by model calibration. Starting values stem from pumping test transmissivities (Table 1) and aquifer thicknesses from the hydrogeological model (Fig. 7). For the horizontal hydraulic conductivity, horizontal isotropy $k_{f x} / k_{f y}=1$ was assumed, whereas a vertical anisotropy $k_{f x} / k_{f z}$ of $1-20$ was determined by model calibration (Sect. 5). A value of 0.25 is assigned to the specific yield for all four aquifers which is in accordance with the pumping test results (Sulzbacher, 2011). Mass transport parameters are presented in Table 3. A porosity value of 0.25 was assumed for the whole ground water body, which
Table 3. Fixed mass transport parameters.

\begin{tabular}{|c|c|}
\hline Porosity [1] & 0.25 \\
\hline Diffusion $\left[\mathrm{m} \mathrm{s}^{-1}\right]$ & $1 \mathrm{E}-9$ \\
\hline Long. dispersion $[\mathrm{m}]$ & 5 \\
\hline Trans. dispersion [m] & 0.5 \\
\hline
\end{tabular}

is consistent with the results of the MRS measurements (Sect. 3.1.2).

\section{Calibration results}

\subsection{Hydraulic calibration}

Due to the fact that during the wet season (February/March) the most comprehensive dataset was available and also HEM and Direct Push data were recorded at this time, March 2010 was selected as reference time for both hydraulic and mass concentration calibration.

Hydraulic heads of 256 reference date measurements were incorporated into the calibration process. Moreover, hydraulic conductivities derived from pumping and slug tests, recharge data and runoff measurements of the open water system were incorporated and adjusted inside the confidence range in order to attain the optimum calibration results.

The transient hydraulic calibration was conducted beginning with the time after the construction of the great south dike in 1934 until March 2010, the latter being the reference time. The calibration was carried out using large time steps for the discretisation of the delivery rate (Fig. 2), in the beginning (firstly $64 \mathrm{yr}$ and then $10 \mathrm{yr}$ ) followed by shorter steps (three steps of one year and then three steps of one month). Due to the inertia of the system, a calibration with a finer time discretisation of the abstraction pattern does not yield better calibration accuracy. Each of these delivery intervals was further discretised by the automatic time step control of FEFLOW into about 45 further time steps, resulting in a total of about 360 time steps for one calibration run for the time span between the dike construction and reference time.

The resulting horizontal hydraulic conductivities $k_{f}$ are in the range of $2 \times 10^{-4}-1 \times 10^{-8} \mathrm{~m} \mathrm{~s}^{-1}$. The vertical anisotropy ratio of $k_{f}$, ranges from 1 (clay) to 20 (stratified sediments with alternating clay layers). The distribution of this factor was also determined by model calibration.

The quality of the calibration can be inferred from a scatter plot, where computed hydraulic heads are plotted against measured ones (Fig. 10). The lower the scattering the higher is the quality of the calibration. The achieved average calibration error (measured minus computed) amounts to about $0.2 \mathrm{~m}$ and is lower than the average error resulting from 


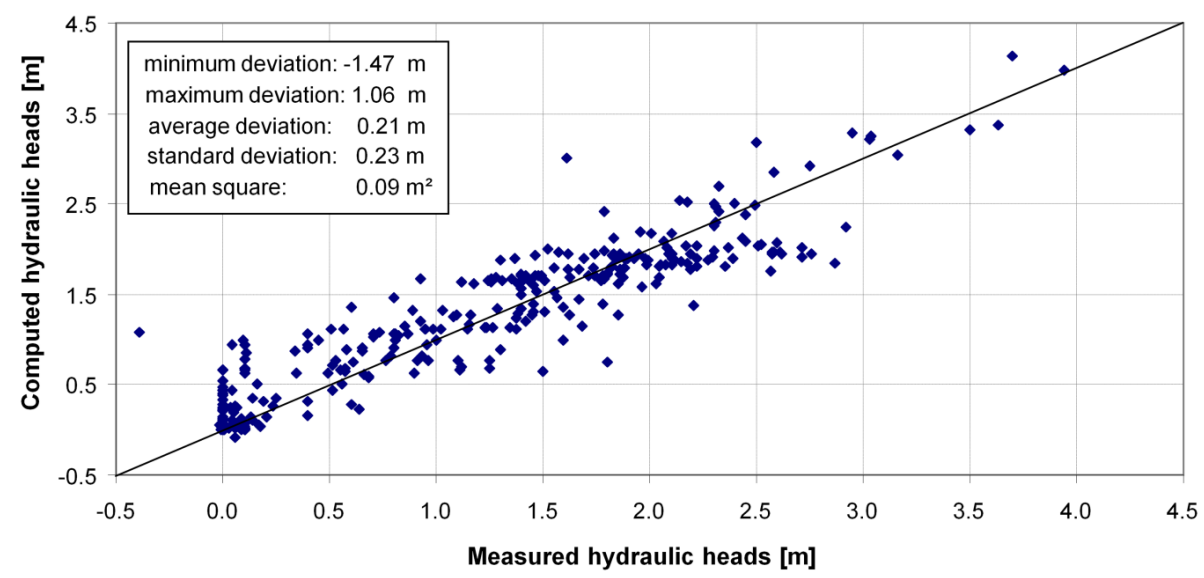

Fig. 10. Statistical results for the hydraulic calibration.
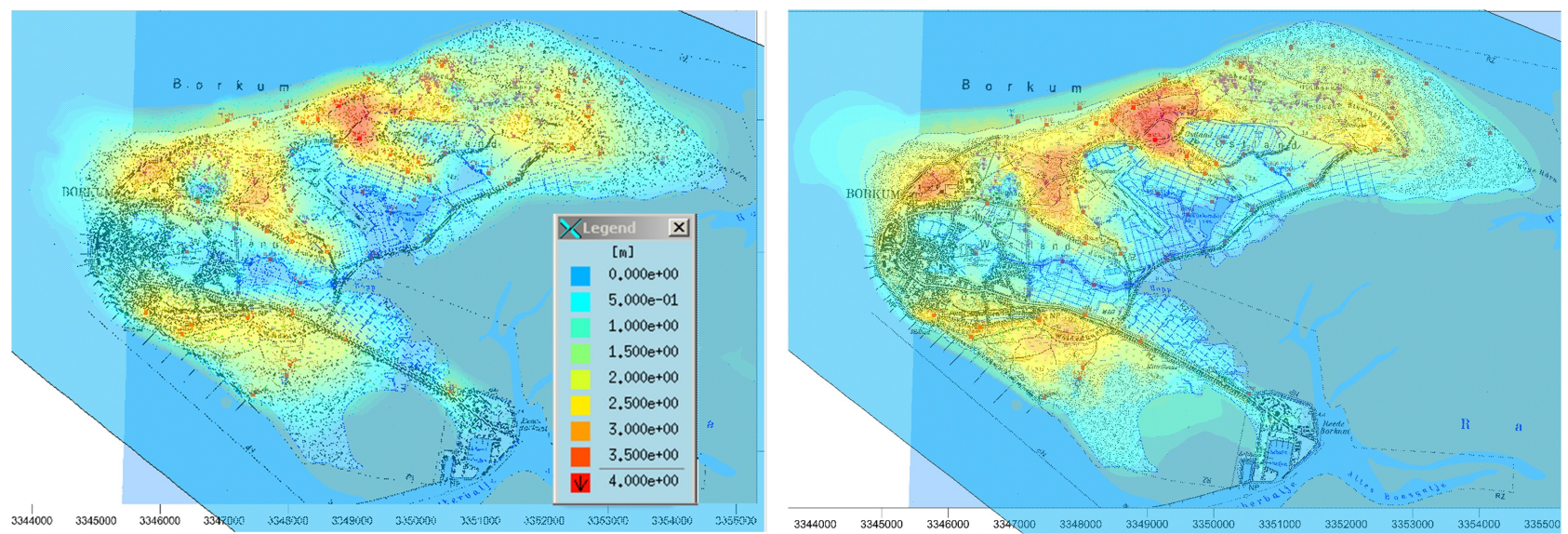

Fig. 11. Direct comparison of measured (left panel) with computed hydraulic heads (right panel).

interpolation between measured hydraulic head values, using for instance a Kriging algorithm.

While the scatter plot yields statistical results for the quality of the calibration, it is hardly possible to get an answer to the question if all relevant structures of the groundwater table could be reproduced sufficiently well by the computed hydraulic heads. The latter are shown by the two fringe plots displayed in Fig. 11. In particular, in the environment of the waterworks, an area of greater significance, the computed and observed groundwater tables are in good agreement.

\subsection{Mass concentration calibration}

Mass concentration or density calibration cannot be performed decoupled from hydraulic calibration. Therefore, it may be necessary to readjust the hydraulic parameters after each change in the TDS distribution after a mass calibration run what can make the calibration process considerably difficult.

Moreover, two-dimensional and three-dimensional numerical computations with simplified models show that sufficiently large freshwater lenses respond extremely slowly to hydrological and hydrogeological events. In the case of typical drinking water lenses of barrier islands such events are the construction of major dikes, changes in the shape of the islands, long-term changes in the drinking water delivery of well fields or major changes in the annual recharge pattern. A freshwater lens like that of Borkum requires more than hundred years until an equilibrium state is re-established after a substantial change in the hydrological/hydrogeological conditions caused by important events. Because of the inertia of the aquifer and the fact that major hydrological events had occurred on Borkum in the past $110 \mathrm{yr}$ the calibration process has to be carried out transient, starting from the last equilibrium state of the aquifer in the year 1900.

Historical topographic and geological maps (Fig. 12, top left and top right panels) show that in the history of Borkum there has been a long lasting (probably more than hundred years) period of stable hydrological conditions with a stable shape of the island, where the island and particularly the freshwater lens was to a large extent divided into two parts with no major changes in the above described influence 

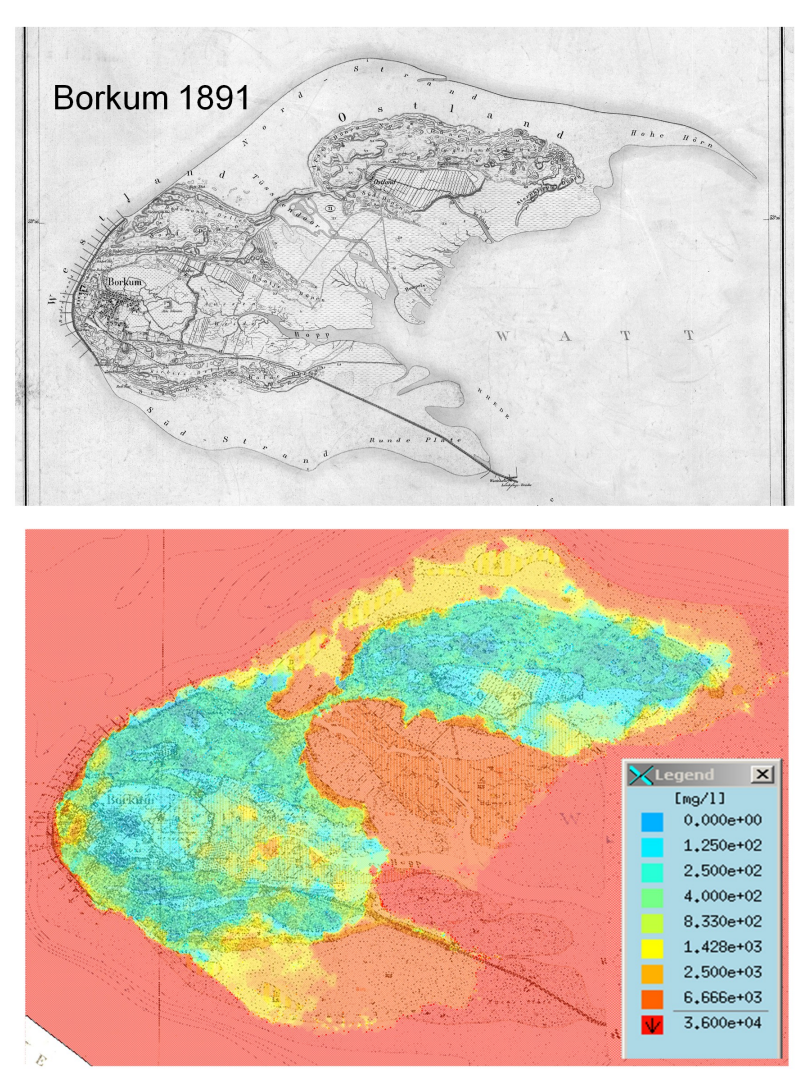

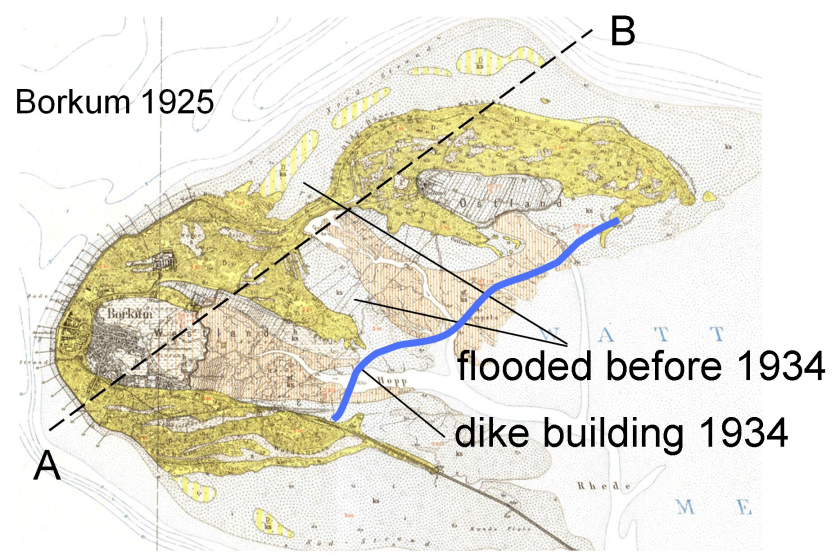

A

B

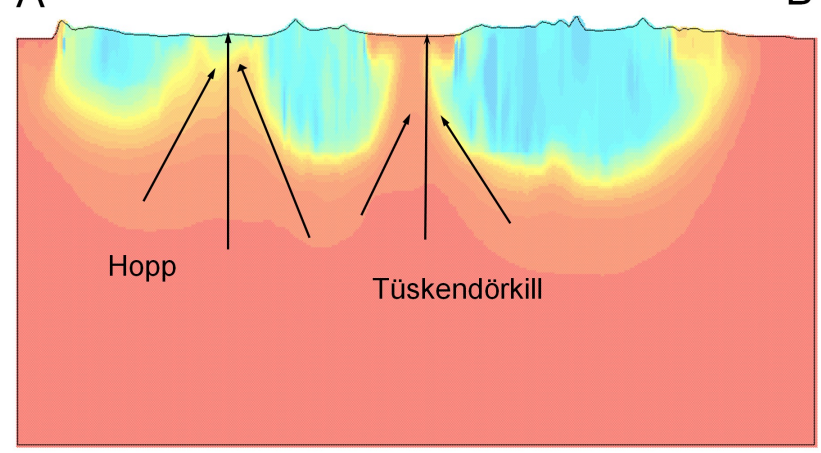

Fig. 12. Inclusion of important factors of hydrological milestones of Borkum into the density calibration by construction of a historical model. Top left and right panels: topographic maps of Borkum 1891 and 1925, bottom panel: historical model of Borkum for the time before the construction of the great south dike (1934), (bottom left panel) TDS distribution at the surface of the groundwater table, bottom right panel: cross-section with TDS distribution A-B through the historical model.

factors. Before WW I started operation at the beginning of the 20th century (Fig. 2, top panel) the freshwater lens was in an equilibrium state.

Due to the abstraction of WW I, the fresh water lens state was changed into a transient one. The most important hydrological event, however, undoubtedly occurred with the construction of the great south dike. The centre of the island was now protected from permanent flooding by sea water and consequently the two divided freshwater lenses began to deform into a single lens. In deeper areas of the lens this process is not yet finished and the freshwater lens is still divided into two parts. A view down to deeper regions of the aquifer is like a view back in time (Fig. 5, top panel, Fig. 13, left panel). In the marshland area, however, the freshwater lens is thinned due to upconing of sea water from below by the system of drains and creeks. This feature is clearly visible in the HEM results.

In 1965 WW II started operation, which had an immense effect on the shape of the freshwater lens. This process is not in a steady state yet.

Consequently, the calibration runs of the TDS distribution have to be performed in transient state, beginning in the year 1900 when the freshwater lens was in an equilibrium state, and ending at the reference time in March 2010. The hydrological/hydrogeological parameters of the "undisturbed" steady state lens at the beginning of the 20th century, previous to the commencing of the delivery of WW I, were translated into initial and boundary conditions of a socalled "historical model". The model then runs until the time of the dike construction in 1934, which includes the delivery of WW I.

For the calibration period, after the dike construction, the model was rebuilt taking into account the changed hydrological features at the surface of the island by adjusting the changed initial and boundary conditions at the surface. These are the initial and boundary conditions for the current, already hydraulically calibrated model as shown in Fig. 9.

The following steps are necessary for the TDS calibration:

1. Construction of constant mass transport boundary conditions from the resulting TDS distribution at the surface layer which has been computed in Sect. 3 using HEM data. 


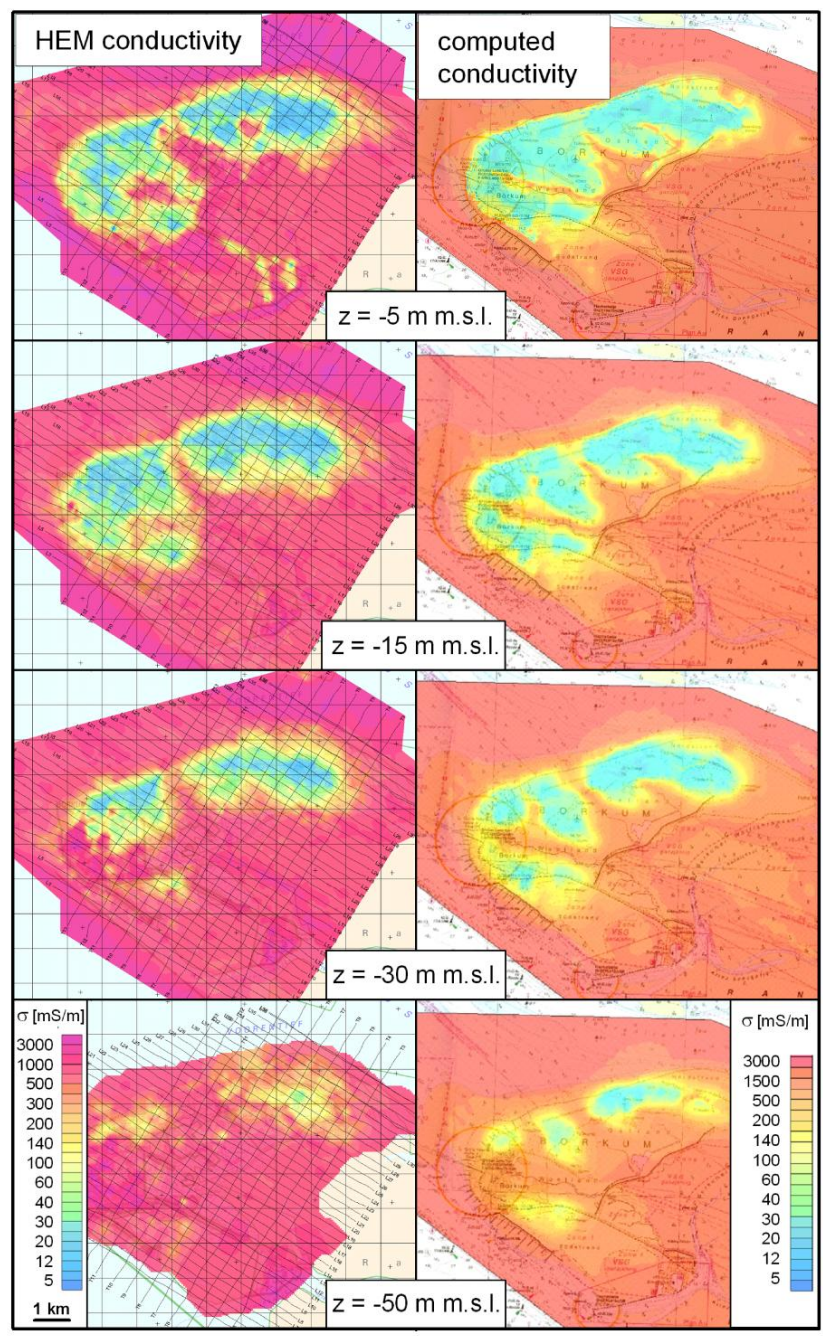

Fig. 13. Comparison between electrical conductivities derived from HEM data (left panel) and computed by the model (right panel) at different depths below sea level. Time of comparison is March 2008.

2. Setup of the historical model. This means that the head and mass transport boundary conditions of the first layers, in particular those of the top layer of the current, already hydraulically calibrated model, have to be adapted to the different historical hydrological conditions by using historical maps from the time before the great south dike was constructed. As no historical recharge data are available, recharge data of the current model (average data for the time period 19611990) are used. Hydraulic conductivity values for the historical model are also obtained from the current model. The aquifer in this model is filled with sea water (TDS $=35000 \mathrm{mgl}^{-1}$ ) and the hydraulic head assigned a value of zero. In the next step the model is run until the equilibrium state is attained. This is possible because in steady state models initial conditions are arbitrary. Figure 12 (bottom left panel) shows densities for constant mass transport boundary conditions adapted to this historical model. The lower, right section of the figure displays a cross-section through the model in an equilibrium state. The upconing of saltwater underneath the rivers Hopp and Tüskendörkill can be clearly seen.

3. Implementation of the delivery data of WW I into the historical steady state model and subsequent transient run until 1934.

4. The so computed density distributions for layers 2-39 are exported from the historical model and imported into the current model. Transient calibration run of the current model to the reference date March 2010 follows, including the delivery pattern of WW I and after 1965 the delivery pattern of WW II (Fig. 2, top panel). The more in the past, the more the fluctuations of the delivery rate of the waterworks can be averaged without affecting the calibration accuracy. The discretisation of the delivery rate and the automatic time stepping of the programme during the calibration of the mass concentration is the same as the one used for the hydraulic calibration (see Sect. 5.1).

5. Comparison of computed TDS distribution with field data for all layers. Estimated model parameters, such as densities, transmissivities or river leakage, have to be adjusted within the confidence intervals (steps 2-5) to get an optimum fit.

Figure 13 shows the result of the TDS calibration of the current model at the time when the HEM campaign was carried out in March 2008. The main structures of the computed freshwater lens (Fig. 13, right panel) match acceptably well the measured ones (Fig. 13, left panel). Differences mainly result from the fact that electromagnetic methods like HEM reveal the bulk electrical conductivity, i.e., it is difficult to distinguish between clay saturated with freshwater and sand saturated with saltwater. These differences are described by the apparent formation factor $F_{\mathrm{a}}$.

TDS values, inferred from WW water probes and Direct Push water samples, agree with the computed ones, in the range of acceptable calibration accuracy, taking into account the underlying uncertainties. This is the case for the well field of WW I Waterdelle as well as for all well groups of WW II Ostland. The results for WW II are presented in Fig. 14. Figure 14 (top left panel) shows a comparison of measured TDS values from Direct Push water samples (DP 60 and DP 37) and a TDS concentration obtained from a manual drilling (B 47a) with computed TDS values in the adjacent screens of wells group $1+2$ of the shallow wells of WW II. Figure 14 (bottom left panel) displays computed TDS values compared with laboratory water sampling results in all screens of WW II Ostland, well fields $3+4$. The agreement is 

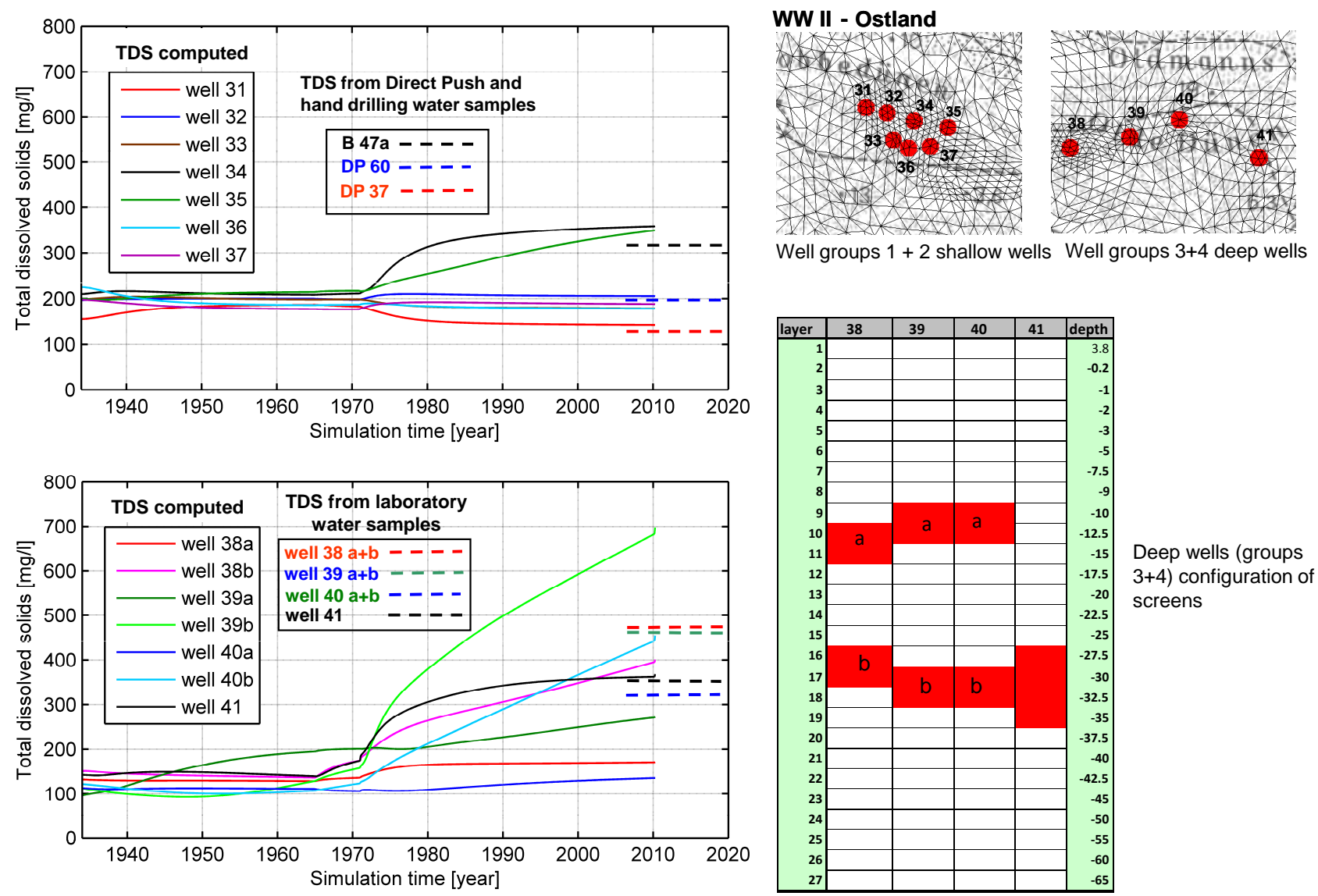

Fig. 14. Comparison of measured and computed TDS concentrations of WW II Ostland, top left panel: well groups $1+2$, bottom left panel: well groups $3+4$, top right panel: location of the well fields, (right) configuration of the well screens for well groups $3+4$. (Depths are given in $\mathrm{m}$ m.s.l.)

acceptable considering that the water samples originate from both screens in the upper and lower aquifer of wells no. 3841 , i.e., the analysed water is a mixture of water from the upper and the lower aquifers.

For the calibration of the TDS concentration in the environment of WW I and II, additional data of the electrical conductivity of the saturated sediments from the two vertical electrode chains, buried in the wells CLIWAT I and II were used. These data offer a high resolution in space and time and are available at a depth between 45 and $65 \mathrm{~m}$ below surface, i.e., at the freshwater-saltwater interface. The TDS values of the pore water, which are computed using the numerical model, are transferred into electrical conductivities by a temperature-dependent factor (Sect. 3.2) and compared with HEM or electrode chain electrical conductivities of the saturated sediments.

The comparison of the computed electrical conductivities of the pore water with the HEM conductivity model at the location of the vertical electrode chain (CLIWAT II) reveals a satisfying agreement in the range of the expected calibration accuracy (Fig. 15). Best fit between HEM and computed electric conductivity is achieved at the top slice (the water table) where a comprehensive high resolution dataset is available. In particular, the apparent formation factor as defined and determined in Sect. 3.1 is known at this location (Fig. 6, top right panel). The match between calculated electric conductivities and those obtained by the vertical electrode chains of CLIWAT I and II is also acceptable. Differences between the smoothed HEM model, electric chain data, and computed values at the freshwater-saltwater interface are mainly caused by apparent formation factors. The latter vary between 1 and 4 for both electrical chain and HEM conductivities, which is typical for salt- and brackish water saturated sediments (Repsold, 1990; Geirnaert and Vandenberghe, 1988; van Overmeeren et al., 1991; TNO-IGG, 1992). Differences between HEM electrical conductivities and the computed ones may also result from the fact that the nearest HEM model has a distance of $89 \mathrm{~m}$ to the CLIWAT II location.

Moreover, during drilling of the CLIWAT I and II boreholes in September 2009 a considerable amount of low conductive drilling mud was pressed through the open hole into the rock, which is still affecting the conductivity data 


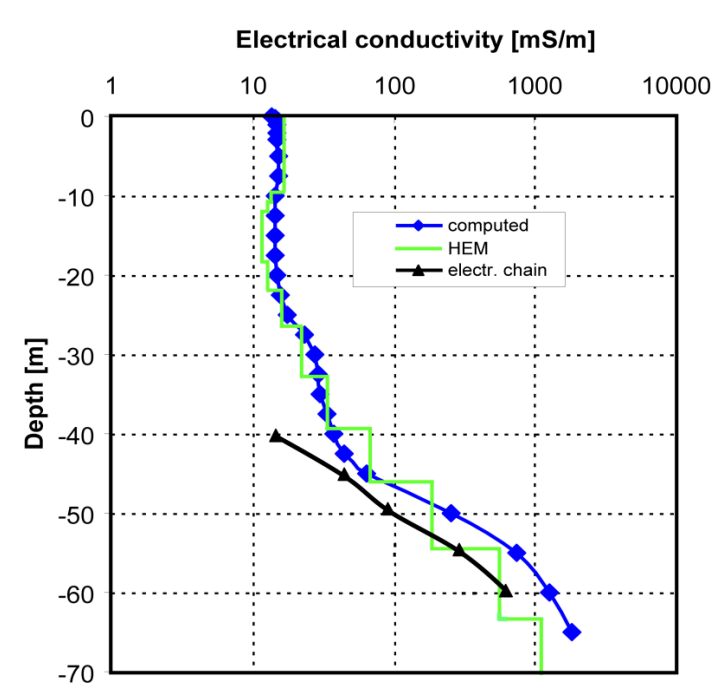

Fig. 15. Comparison of HEM conductivities (green) and CLIWAT II vertical electrode chain conductivities (black) with conductivities computed by the model (blue).

recorded by the vertical chain, especially in deeper regions of the freshwater lens. A detailed transient analysis of the vertical chain data shows that at recording time (27 August 2010) the freshwater lens had not yet recovered from these disturbances. The obvious trend of increasing conductivities may still last several years.

\section{Simulation results}

\subsection{Simulations for future climate scenarios}

The Norddeutsches Klimabüro provides climate change scenarios for the German North Sea coastal area (http://www. norddeutscher-klimaatlas.de). According to this, an increase in the average annual temperature of $2.9^{\circ} \mathrm{C}$ and for the annual precipitation of about $10 \%$ (summer $-5 \%$ and winter $+25 \%$ ) is expected until the year 2100 . These values are the possible mean change depending on results from several regional climate calculations based on multiple emission scenarios including the A2 scenario. Climate change effects on groundwater recharge and discharge to streams will vary seasonally due to wetter winters and dryer summers.

From a groundwater perspective, rising sea level has special significance to low-lying coastal areas and to islands. The amount of local sea level rise is dependent on the predicted worldwide sea level response on climate change and the local land subsidence/uplift.

The amount of sea-level rise for the German North Sea using the IPCC scenarios has been computed by Rahmstorf (2007). According to the A2 scenario, including land subsidence, the sea level will rise by $1 \mathrm{~m}$ from 1995 until 2100 or $0.94 \mathrm{~m}$ from 2010 to the year 2100 . This value is used in our study for the simulations with the numerical model of Borkum.

The altitude of the groundwater table was mapped and visualised. Due to the enhanced annual precipitation scenarios we used an enhanced, linearly increasing annual groundwater recharge of $+10 \%$ for 2100 (average scenario) and an annual recharge of $+5 \%$ for 2100 (conservative scenario). For the delivery rates of WW I and WW II a constant value of $380000 \mathrm{~m}^{3} \mathrm{a}^{-1}$ (average delivery 1934-2010) and $480000 \mathrm{~m}^{3} \mathrm{a}^{-1}$ (average delivery 1971-2010) was used, respectively. Model computations reveal that due to the inertia of the freshwater lens model seasonal variations of the delivery rates are negligible. To achieve correct prognosis results, the level of constant head boundary conditions representing the surface of the sea water was shifted for each time step during simulation by means of a linear function, beginning with $0 \mathrm{~m}$ in the year 2010 and ending with 0.96 in the year 2100 . Moreover, the area covered by boundary conditions of this type had to be extended more towards the shore according to the risen mean sea level (Fig. 17, right panel). Additionally, the mass transport boundary conditions were adapted to the full sea water concentration in areas consistent with the progressed mean high tide for 2100 (blue area in Fig. 17, right panel).

The simulation results show that the general shape of the groundwater table will be affected only slightly as shown in Fig. 16. Due to the enhanced recharge and the increased sea level the groundwater table will rise until 2100 in the dune areas by about $0.4 \mathrm{~m}$ for the average scenario and $0.3 \mathrm{~m}$ for the conservative scenario. This can be seen in the fringe plot by the colour transition from yellow to orange to red. In the drained marshlands behind the dikes it will be nearly not affected (Fig. 16). But enhanced drainage is necessary and the outflow from the open water will increase by about $50 \%$ for both the average and the conservative scenario.

Figure 17 (left panel) shows the island during mean high tide today (2010). The sea level according to these periodical events amounts to $+1.15 \mathrm{~m}$ m.s.l. Areas higher than this level are marked red while areas below mean high tide, which are regularly flooded, are marked blue. The figure shows that at this time only some small strips of the beaches are flooded regularly, whereas lower laying areas which are located more inside the island (marked with hatched blue) are protected by the south dike and the dunes. Compared to the situation in 2010, the situation in 2100 will change considerably (average scenario: recharge $+10 \%$ ). The result is that the mean high tide will rise by $0.94 \mathrm{~m}$ to a flooding level of $2.09 \mathrm{~m}$ and, thereby flooding about $25 \%$ of the island occurs outside the protecting dunes and dikes (Fig. 17, right panel). Without protection measures like fillings with sand or other appropriate material large parts of the low-lying natural reserves and beaches in the south and north east regions of the island will be covered by the Wadden Sea.

The model results for the year 2100 in terms of TDS show that sea-level rise until 2100 will not affect essentially the 

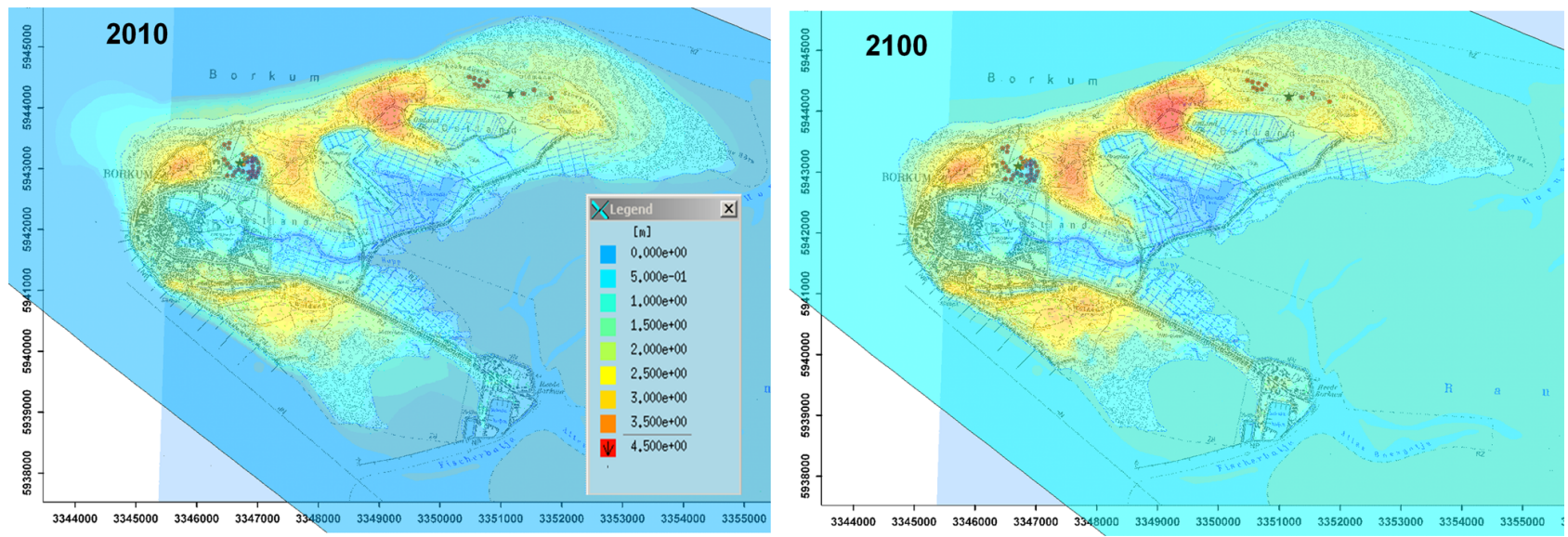

Fig. 16. Computed groundwater table for 2010 (left panel) and 2100 (right panel) by using the IPCC-A 2 emission scenario. The groundwater recharge will increase linearly by $10 \%$ (average scenario).
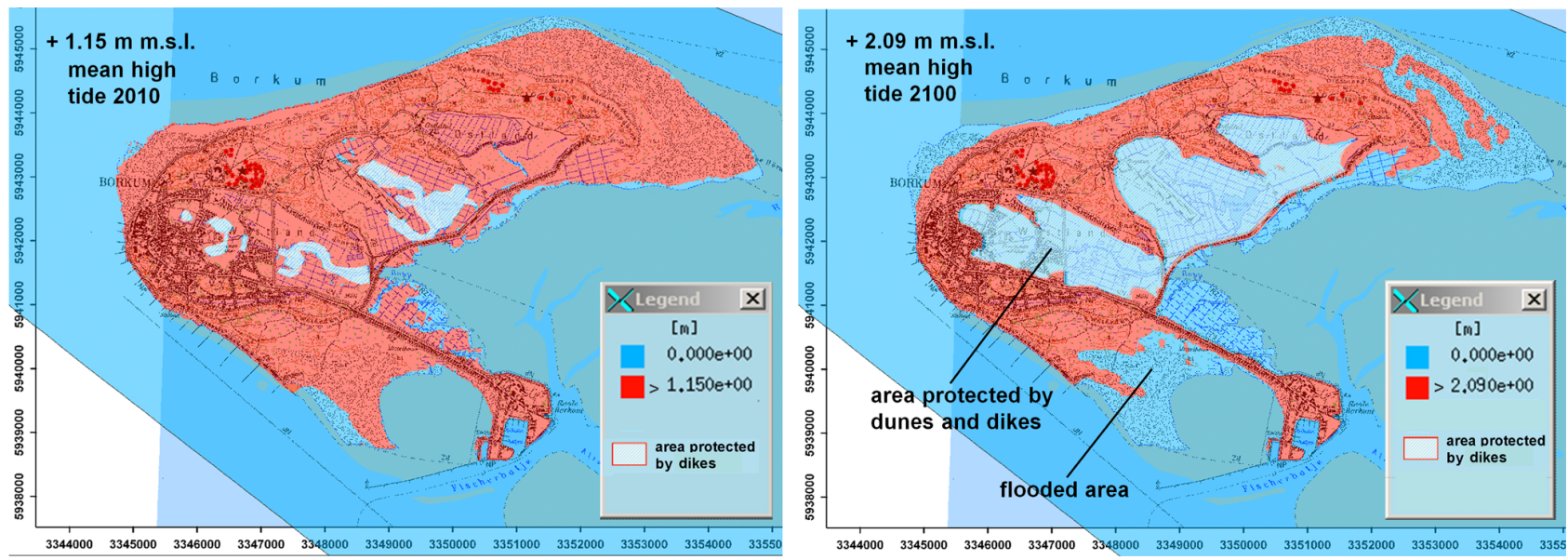

Fig. 17. Left panel: Island of Borkum during mean high tide at present time compared with the simulated A2 scenario for year 2100 (right panel). Blue marked areas are flooded permanently by the tide, hatched blue areas correspond to domains protected from flooding by dunes and dikes being higher than mean high tidal level (red area). The result is that the mean high tide is $0.94 \mathrm{~m}$ higher and thereby flooding about $25 \%$ of the island.

general shape of the freshwater lens (Fig. 18). At greater depths, however, salinisation of the lens is present particularly in the environment of the waterworks, where upconing of sea water and saltwater intrusion will threaten the drinking water quality. In some areas sufficiently far away from the waterworks, in the centre of the dunes, the lens profits by the enhanced recharge and refreshing can be observed by the blue colouration of the freshwater lens in this region, particularly at a depth of $-30 \mathrm{~m}$ m.s.l. (Fig. 18).

At the boreholes CLIWAT I and II we can look at the effects in more detail. Vertical profiles of the TDS concentration of the pore water are computed at the reference time March 2010 (Fig. 19, blue curve) and for the year 2100 (Fig. 19, dashed black curve). The computations illustrate that until the end of this century the salinisation in the vicinity of the well fields will increase considerably and may become a problem for the quality of the delivered drinking water, especially for the deep-lying well screens of WW II.

This feature can also be seen in Fig. 20 where the computed TDS concentration versus time during the period 2010-2100 is illustrated for all water supply wells of the waterworks. A linear increase of the groundwater recharge to a maximum of $+5 \%$ until the year 2100 was used for the computations (conservative assumption). The figure shows that until 2100 some of the TDS curves, in particular 3 out of 4 TDS curves in the deep screens of WW II - Ostland, substantially exceed the permitted $\mathrm{NaCl}$ concentration for drinking water. Direct Push observations and water probe analysis show that $\mathrm{NaCl}$ concentrations are only slightly lower than TDS concentrations for most areas of the freshwater lens (Winter, 2008a,b). An appropriate management of the water resources is required to prevent excessive salinisation of 


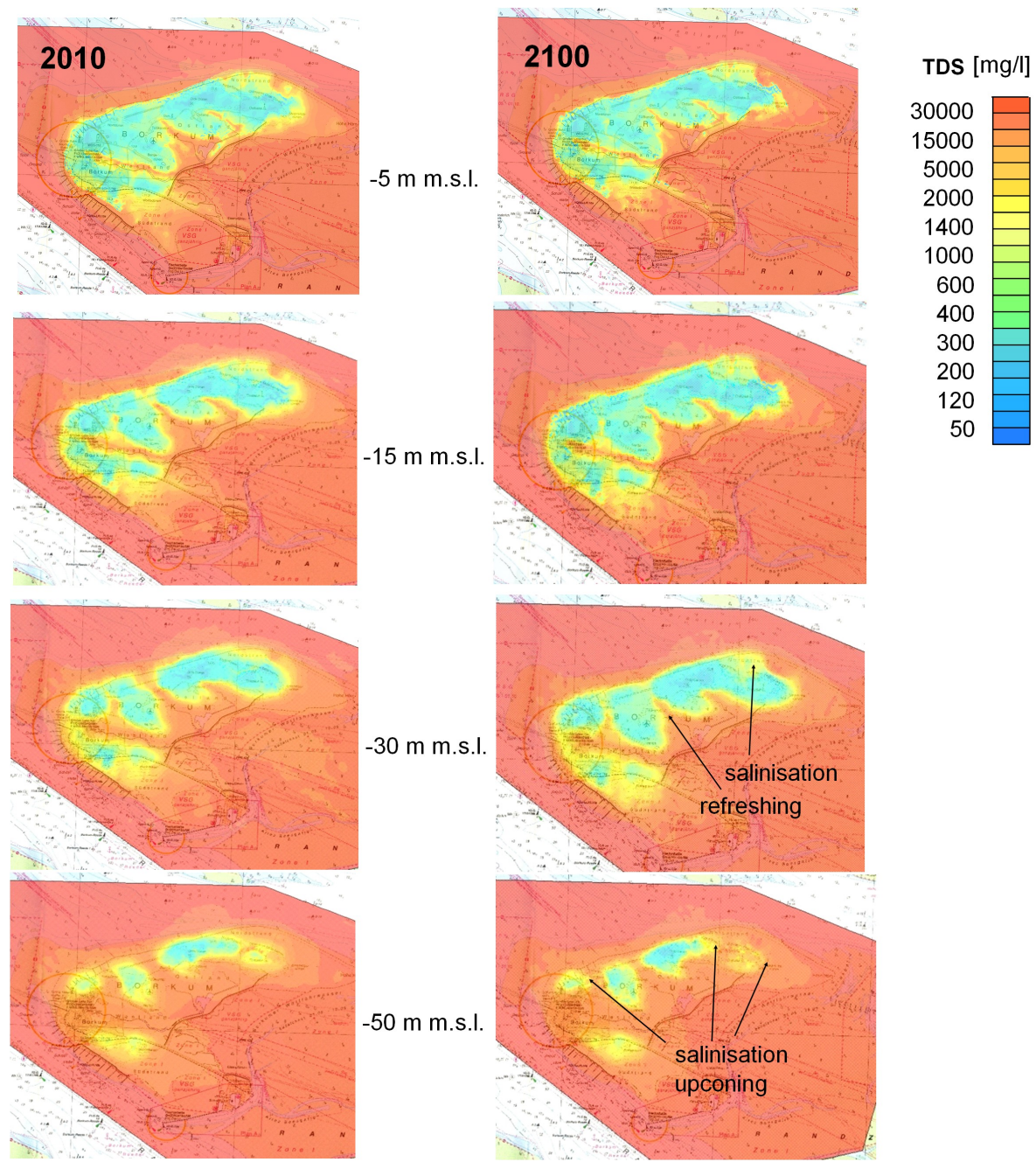

Fig. 18. Computed freshwater lens in 2010 (left panel) and 2100 (right panel).

the drinking water resources and deterioration of the groundwater chemical status according to the EU Groundwater Directive.

\subsection{Possible solutions for the future}

On Borkum protection measures are necessary to prevent the water supply from excessive salinisation caused by overexploitation and sea level rise. Utilising the density dependent groundwater flow model the location of the respective water supply wells in the waterworks can be optimised to prevent exceeding salinisation beyond the permitted limits. For the case of EU member states this includes not only the EU drinking water standards, but also properly derived groundwater threshold values according to the EU Water Framework and Groundwater directives (Hinsby et al., 2008; Wendland et al., 2008).

Figure 21 (left panel) shows the supply wells of WW I (top) and WW II (below) (red circles) together with the TDS distribution computed for 2100 at depths of the waterworks screens. Possible locations for new wells which could relieve the waterwork and prevent the wells field from upconing of saltwater are marked blue and are located at positions where sufficient water quality can be expected for 2100 . Wells which should be closed because of excessive salinisation until 2100 are marked brown. The computed TDS curves for all water supply wells (Fig. 21, right panel) demonstrate that solutions for the well field configuration can be found to keep water quality below the required limit for $\mathrm{NaCl}$ concentration. In this way it is possible to maintain drinking water quality without being forced to reduce the amount of extraction for more than $100 \mathrm{yr}$. Numerical simulations can help to find adequate locations for possible new wells.

In regards to the certainty of these results the evolution of the future recharge is a sensitive key parameter estimated only from precipitation, which implies much insecurity. To see how certain the computed density distribution for the new well configuration is, additional sea-level rise scenarios 


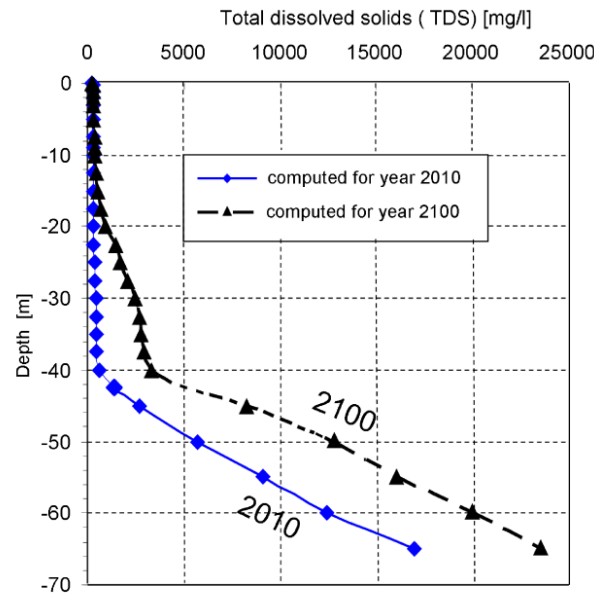

CLIWAT I - Waterdelle

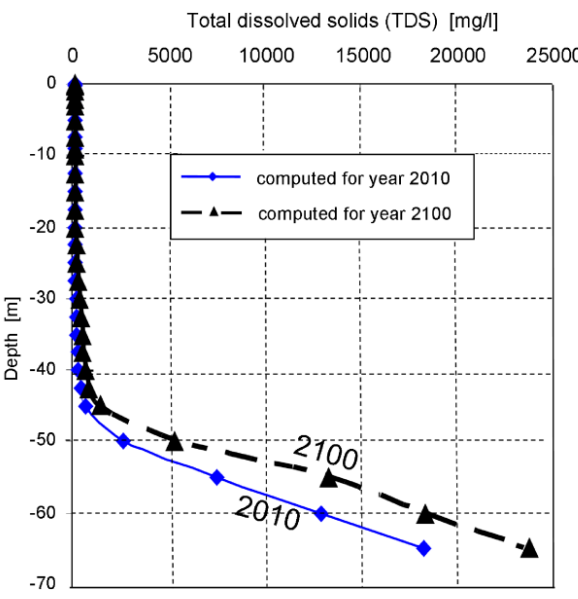

CLIWAT II - Ostland

Fig. 19. Spatiotemporal evolution of the vertical mass concentration (TDS) for the years 2010 and 2100 at the wells CLIWAT I and II. The concentrations are computed using the groundwater model.
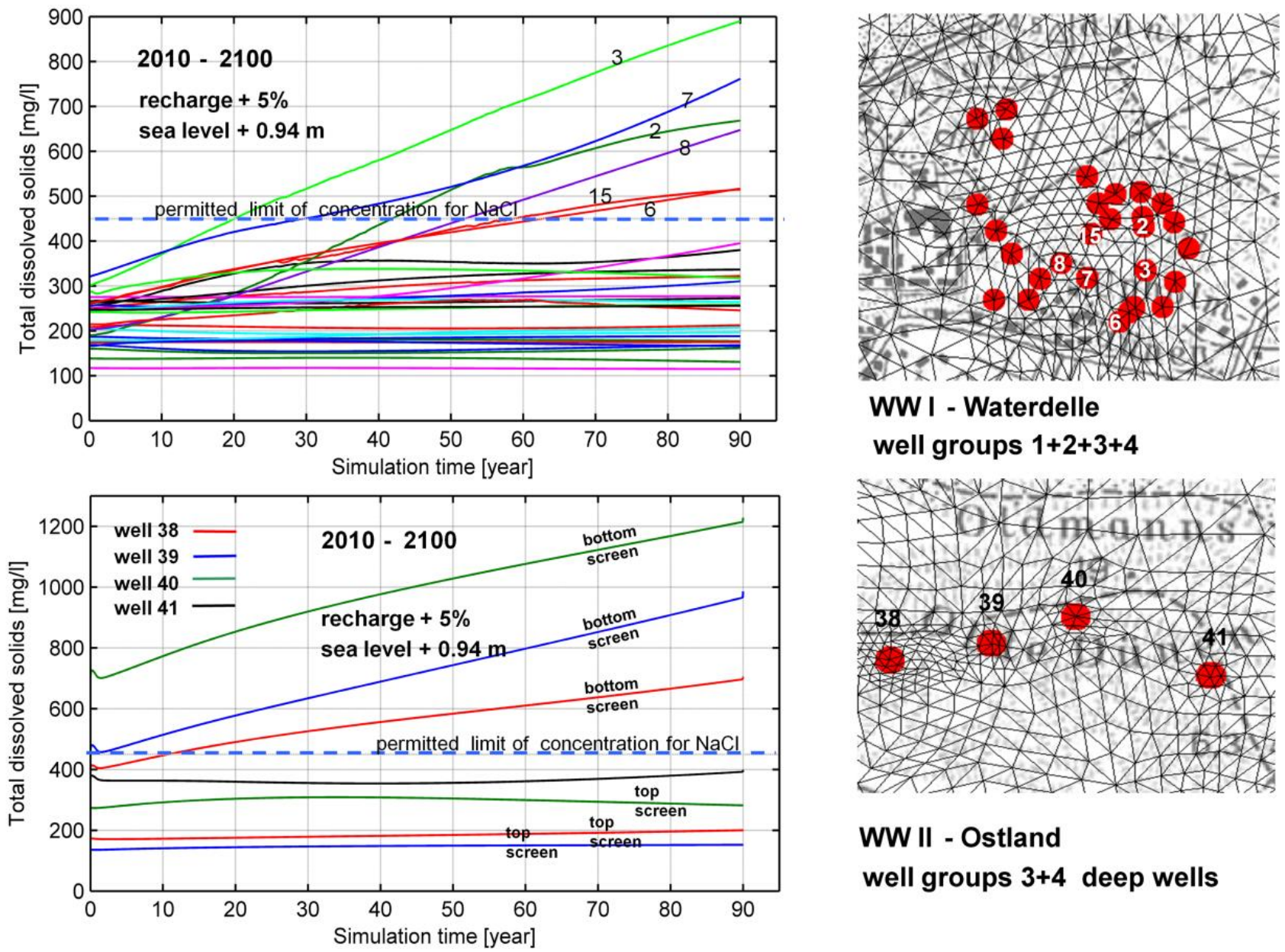

Fig. 20. TDS concentration $\left[\mathrm{mgl}^{-1}\right.$ ] computed in the screen of the water supply wells of WW I Waterdelle (top left panel) and WW II Ostland (below left panel). In the right part of the figure location maps of the well fields are presented. 

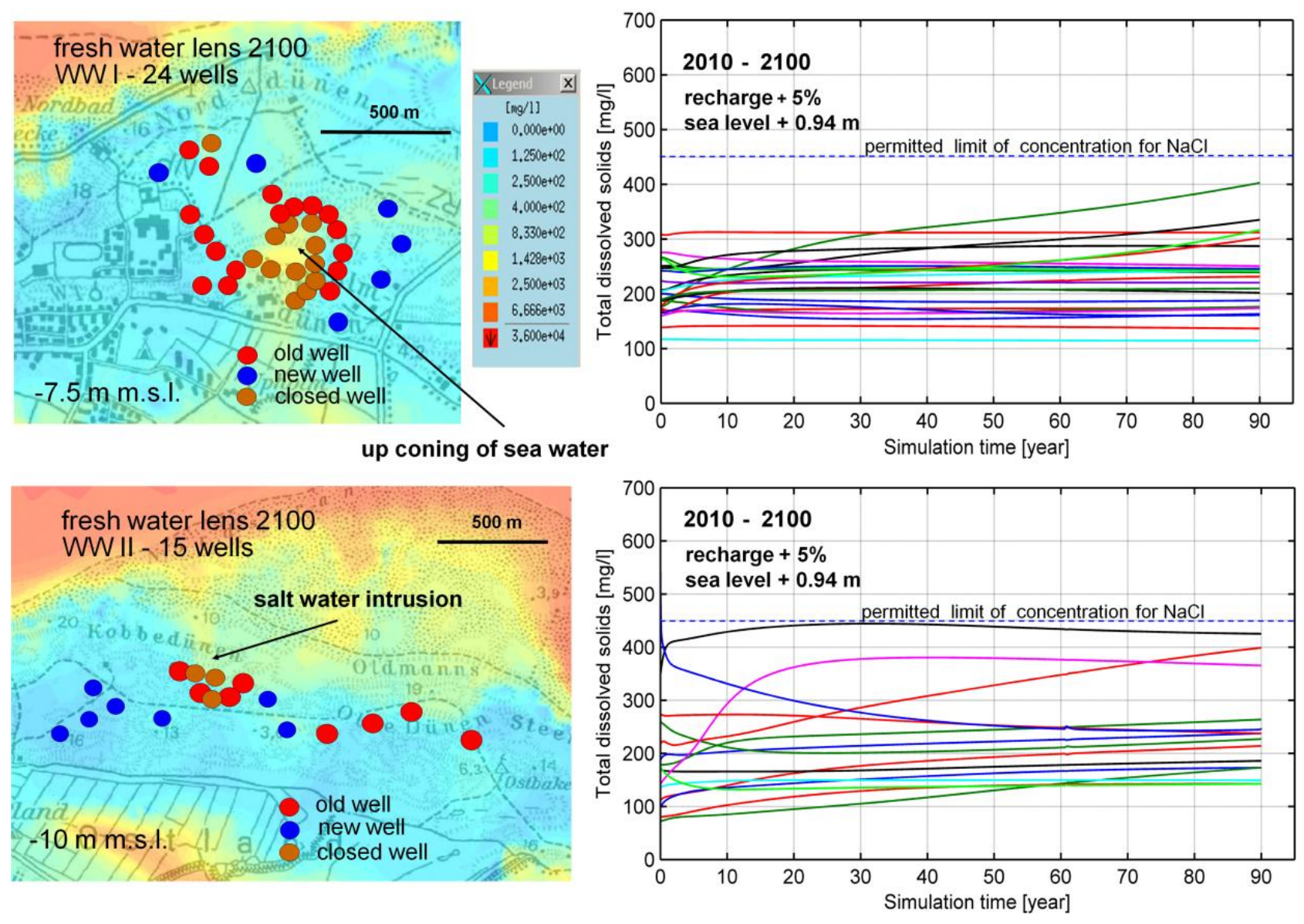

Fig. 21. Spreading of well fields as protection measure from excessive salinisation of the water supply. Location of old wells, new wells and closed wells (left panel); the deep screens of WW II (Fig. 14, bottom right panel) were also closed. Development of TDS concentration in the supply wells with time (right panel). WW I Waterdelle (top panel), WW II Ostland (below panel).

with different recharge rates from 2010 until 2100 (extremely dry scenario with no recharge increase, average scenario with linear recharge increase of $0-10 \%$ and linear increase of recharge $0-15 \%$, wet scenario) were simulated. Model results show that for all these scenarios the obtained well configurations for both water works (Fig. 21) are valid and the salinisation of the drinking water for all delivery wells remains below the permitted limit.

The topography of low-lying areas predominantly located in the south and northeast of the island and endangered by flooding under an increased sea level (Fig. 17) should be adapted to the rising sea level by sand fillings as it has been already carried out successfully on other barrier islands like Sylt.

The North Sea region, in particular the German Bight, can be a target of heavy storm flood events. Under extreme weather conditions and an enhanced sea level of $1 \mathrm{~m}$, storm floods can attain altitudes in the order of $4 \mathrm{~m}$ m.s.l. (one-in50 -yr event). It is clear that protection measures are necessary. The altitudes of the dikes have to be controlled and adapted where required. Moreover, dune valleys potentially being gateways for the flood have to be banked up with appropriate material such as sand to maintain their protective function.

\section{$7 \quad$ Summary and conclusions}

We developed a density dependent groundwater flow model for the North Sea Island of Borkum. The model was successfully calibrated on the basis of hydrological and geophysical data. Verification runs of the calibrated model with the data obtained from field work show a good agreement for the measured and computed hydraulic heads as well as for the measured and computed density distributions.

The integration of large-scale HEM data covering the entire model area and electrical conductivity data obtained from vertical electrode chains CLIWAT I and II on a local scale has proven to be very valuable for a reliable model calibration. Moreover, the integration of these geophysical data provides a better understanding of the hydrological processes involved in the spatiotemporal evolution of the islands freshwater lens. 
These processes have to be taken into consideration for the transient model calibration.

The thoroughly calibrated groundwater flow model is capable of predicting the spatial and temporal development of parameters like hydraulic heads, electrical conductivity and salinity under changing climate conditions and sea level.

Of particular interest will be the development of the future concentrations of total dissolved solids in the delivered drinking water from the waterworks supply wells. Modelling results obtained in this study demonstrate the progressing salinisation of the groundwater along the vertical profiles of the two CLIWAT boreholes beneath the waterworks with time until the year 2100. This $\mathrm{NaCl}$ concentration of the extracted water could become a serious problem for the drinking water supply, and the groundwater chemical status. Effective measures will be necessary to properly tackle this severe problem in order to ensure good drinking water quality and comply with the requirements of EU directives.

The results provide an important input and a strong tool for current and future quantitative and chemical status assessments of groundwater according to the Water Framework Directive and Groundwater Directive, as well as for the planning of strategies for flood defence. The results will also be accompanied with guidelines and recommendations for the management of the water supply and the protection of the groundwater resources.

Our approach is essentially consistent with the recommendations towards best practice for assessing the impacts of climate change on groundwater given by Holman et al. (2012) and for the application of, e.g., electromagnetic measurements in model calibration (Carrera et al., 2010).

Based on modelling results, the groundwater resources in Borkum must be protected to meet the current and future demands for domestic water.

The need to progressively adapt to the predicted climate changes is urgent. This modelling study and other results of the CLIWAT project (de Louw et al., 2011; Oude Essink et al., 2010) provide a robust basis on which future adaptations can be made.

The results of the model analysis are also applicable to other typical barrier island of the North Sea Region, especially the East Frisian Islands.

Acknowledgements. CLIWAT is co-financed by the European Union under the Interreg IVB North Sea Region Programme (project ID 35-2-1-08). We thank the engineering office Hydrogeology Sebastian Winter and the water supplier "Wirtschaftsbetriebe der Stadt Nordseeheilbad Borkum Stadtwerke Borkum GmbH" (Axel Held) for data supply and extensive support during field work. The drilling data were provided by the "Landesamt für Bergbau, Energie und Geologie (LBEG)" in Hannover. Last not least we thank the anonymous referees for their thorough review of this work.

Edited by: P. de Louw

\section{References}

Agmon, S., Douglis, A., and Nirenberg, L.: Estimates near the boundary for solutions of elliptic partial differential equations satisfying general boundary conditions, Comm. Pure Appl. Math., 12, 623-727, doi:10.1002/cpa.3160120405, 1959.

Bear, J., Cheng, A. H.-D., Sorek, S., Ouazar, D., and Herrera, I. (Eds.): Seawater Intrusion in Coastal Aquifers - Concepts, Methods and Practices, Kluwer Academic Publishers, 1999.

Behre, K.-E.: (Landschaftsgeschichte Norddeutschlands, Wachholtz-Verlag, Neumünster, 2008.

BSH Bundesamt für Seeschifffahrt und Hydrographie: Meeresoberflächentemperatur, http://www.bsh.de/de/ Meeresdaten/Beobachtungen/Meeresoberflaechentemperatur/ anom.jsp\#SSTM (last access: 7 March 2012), 2009.

Carrera, J., Hidalgo, J. J., Slooten, L. J., and Vazquez-Sune, E.: Computational and conceptual issues in the calibration of seawater intrusion models RID E-7251-2011, Hydrogeol. J., 18, 131145, 2010.

Cooper Jr., H. H., Kohout, F. A., Henry, H. R., and Glover, R. E.: Sea water in coastal aquifers, US Geol. Survey Water-Supply Paper 1613 C, Washington, 1964.

de Louw, P. G. B., Eeman, S., Siemon, B., Voortman, B. R., Gunnink, J., van Baaren, E. S., and Oude Essink, G. H. P.: Shallow rainwater lenses in deltaic areas with saline seepage, Hydrol. Earth Syst. Sci., 15, 3659-3678, doi:10.5194/hess-15-36592011, 2011.

DHI Wasy GmbH, http://www.feflow.info/uploads/media/white papers_vol1_01.pdf (last access: 8 October 2012), 2009.

Fein, E., Kröhn, K. P., Noseck, U., and Schneider, A.: Modelling of field-scale pollutant transport, Final Report, Ges. für Anlagenund Reaktorsicherheit, GRS, Braunschweig, 2008.

Geirnaert, W. and Vandenberghe, J.: Applied Geophysics for Groundwater Exploration and Geological Mapping, Instituut voor Aardwetenschappen, Vrije Universiteit, Amsterdam, 1988.

Grinat, M., Südekum, W., Epping, D., Grelle, T., and Meyer, R.: An automated electrical resistivity tomography system to monitor the freshwater/saltwater zone on a North Sea Island, Ext. Abstr., A20, Near Surface Geoscience Division of EAGE, Zürich, 2010.

Günther, T. and Müller-Petke, M.: Hydraulic properties at the North Sea island of Borkum derived from joint inversion of magnetic resonance and electrical resistivity soundings, Hydrol. Earth Syst. Sci., 16, 3279-3291, doi:10.5194/hess-16-32792012, 2012.

Herzberg, B.: Die Wasserversorgung einiger Nordseebäder, J. Gasbel. Wasservers., 44, 815-819, 1901.

Heyen, H. and Dippner, J. W.: Salinity variability in the German Bight in relation to climate variability, Tellus A, 50, 545-556, 1998.

Hinsby, K., Bjerg, P. L., Andersen, L. K., Skov, B., and Clausen, E. V.: A mini slug test method for determination of a local hydraulic conductivity of an unconfined sandy aquifer, Journal of Hydrology, Elsevier Science Publishers B.V., Amsterdam, 36, 87-106, 1992.

Hinsby, K., de Melo, M. T. C., and Dahl, M.: European case studies supporting the derivation of natural background levels and groundwater threshold values for the protection of dependent ecosystems and human health RID C-1806-2008, Sci. Total Environ., 401, 1-20, 2008. 
Holman, I. P., Allen, D. M., Cuthbert, M. O., and Goderniaux, P.: Towards best practice for assessing the impacts of climate change on groundwater, Hydrogeol. J., 20, 1-4, 2012.

Holzbecher, E.: Modeling density-driven flow in porous media: basics, numerics, software, Springer Verlag, Berlin, Heidelberg, New York, 1998.

Igel, J., Günther, T., and Kuntzer, M.: Ground-penetrating radar insight into a coastal aquifer: the freshwater lens of Borkum Island, Hydrol. Earth Syst. Sci. Discuss., 9, 3691-3720, doi:10.5194/hessd-9-3691-2012, 2012.

IPCC: Synthesis Report, Summary for Policymakers. Assessment of Working Groups I, II, and III to the Fourth Assessment Report of the IPCC, Cambridge University Press, New York, NY, USA, 2007.

Katsube, T. J., Issler, D. R., Loman, J., and Cox, W. C.: Apparent formation-factor and porosity variation with pressure for Cretaceous shale of the Western Canada Sedimentary Basin, southern Alberta, Current Research 2000-E6, Geological Survey of Canada, Natural Resources Canada, Ottawa, 2000.

Krawczyk, C. M., Polom, U., Trabs, S., and Dahm, T.: Sinkholes in the city of Hamburg - New urban shear-wave reflection seismic system enables high-resolution imaging of subrosion structures, J. Appl. Geophys., 78, 133-143, doi:10.1016/j.jappgeo.2011.02.003, 2012.

Kinzelbach, W. K. H.: Methods for simulation of pollutant transport in ground water, A model comparison, in: Proc. Solving Ground Water Problems With Models, Conference and Exposition, Vol. 1, Denver, Colorado, USA, 656-675, 1987.

Lee, C. H. and Cheng, R. T. S.: On seawater encroachment in coastal aquifers, Water Resour. Res., 10, 1039-1043, 1974.

Oude Essink, G. H. P., van Baaren, E. S., and de Louw, P. G. B.: Effects of climate change on coastal groundwater systems: A modeling study in the Netherlands, Water Resour. Res., 46, W00F04, doi:10.1029/2009WR008719, 2010.

Petersen, J., Pott, R., Janiesch, P., and Wolff, J. (Eds.): Umweltverträgliche Grundwasserbewirtschaftung in hydrogeologisch und ökologisch sensiblen Bereichen der Nordseeküste, Husum Druck- und Verlagsgesellschaft, Husum, Germany, 2003.

Polom, U., Druivenga, G., Großmann, E., Grüneberg, S., and Rode, W.: (in German) Transportabler Scherwellenvibrator, DPMA Patentschrift DE10327757B4, DPMA München, 26 May 2011.

Post, V. E. A.: Fresh and saline groundwater interaction in coastal aquifers: Is our technology ready for the problems ahead, Hydrogeol. J., 13, 120-123, doi:10.1007/s10040-004-0417-2, 2005.

Post, V. E. A. and Abarca, E.: Preface: Saltwater and freshwater interactions in coastal aquifers, Hydrogeol. J., 18, 1-14, doi:10.1007/s10040-009-0561-9, 2010.

Rahmstorf, S.: A Semi-Empirical Approach to Projecting Future Sea-Level Rise, Science, 315, 368-370, doi:10.1126/science.1135456, 2007.

Rasmussen, P., Sonnenborg, T. O., Goncear, G., and Hinsby, K.: Assessing impacts of climate change, sea level rise, and drainage canals on saltwater intrusion to coastal aquifer, Hydrol. Earth Syst. Sci. Discuss., 9, 7969-8026, doi:10.5194/hessd-9-79692012, 2012.
Repsold, H.: Geoelektrische Untersuchungen zur Bestimmung der Süßwasser-/Salzwasser-Grenze im Gebiet zwischen Cuxhaven und Stade, Geologisches Jahrbuch Reihe C, Heft 56, Hannover, 1990.

Siemon, B., Ibs-von Seht, M., Meyer, U., Pielawa, J., Steuer, A., Voß, W., and Wiederhold, H.: Technischer Bericht zur Befliegung der Insel Borkum März 2008, Technical Report, BGR archives no. 0128656, Hannover, 2009a.

Siemon, B., Christiansen, A. V., and Auken, E.: A review of helicopter-borne electromagnetic methods for groundwater exploration, Near Surf. Geophys., 7, 629-646, 2009 b.

Streif, H.: Das ostfriesische Küstengebiet, 2. Auflage, Gebr. Bornträger, Berlin, Stuttgart, 1990.

Südekum, W., Grinat, M., Winter, S., Epping, D., Grelle, T., and Meyer, R.: Vertikale Elektrodenstrecken zur Erkundung von Änderungen im Salz-Süßwasser-Übergangsbereich auf Borkum, bbr Fachmagazin für Brunnen und Leitungsbau, Bonn, 12, 6871, 2009.

Sulzbacher, H.: Technical report on Field Work in CLIWAT Area D Borkum, Technical Report 2009-2010, Technical Report, LIAG, Hannover 2011.

Thorenz, C.: Model adaptive simulation of multiphase and density driven flow in fractured and porous media. Dissertation, Institut für Strömungsmechanik Universität Hannover, 2001.

TNO-IGG: Introduction to geophysical well logs, a practical course for groundwater studies, TNO Instituut voor Grondwater en GeoEnergie, Delft, 1992.

van Overmeeren, R. A., Mulder, M. H., and Meekes, J. A. C.: Computer aided analysis and interpretation of geophysical data, Dienst Grondwaterverkenning TNO, Delft, 1991.

Voss, C.: Editor's message: Groundwater modeling fantasies part 1, a drift in the details, Hydrogeol. J., 19, 1281-1284, $2011 \mathrm{a}$.

Voss, C.: Editor's message: Groundwater modeling fantasies part 2, down to earth, Hydrogeol. J., 19, 1455-1458, 2011 b.

Wendland, F., Berthold, G., Blum, A., Elsass, P., Fritsche, J., Kunkel, R., and Wolter, R.: Derivation of natural background levels and threshold values for groundwater bodies in the Upper Rhine Valley (France, Switzerland and Germany) RID C-49392008 RID C-4934-2008, Desalination, 226, 160-168, 2008.

Winter, S.: Erkundung und Bewertung von Grundwasserbelastungen im Bereich der Süßwasserlinsen Borkum, Hydrogeologie Sebastian Winter, Ingenieurbüro für Hydrologie, Sedimentologie und Wasserwirtschaft, Leer, 2008a.

Winter, S.: Erkundung und Bewertung von Grundwasserbelastungen im Bereich der Süßwasserlinsen Borkum - Teilprojekt Direct-Push-Sondierung - Ergebnisbericht, Hydrogeologie Sebastian Winter, Ingenieurbüro für Hydrologie, Sedimentologie und Wasserwirtschaft, Leer, 2008b.

Winter, S.: Hydraulische Tests an den Tiefbrunnen 38 und 40 des Ostlandes - Ergebnisbericht, Hydrogeologie Sebastian Winter, Ingenieurbüro für Hydrologie, Sedimentologie und Wasserwirtschaft, Leer, 2009. 